\title{
Lag Time of Heat Conduction in Conditions of Growing Greenery Cover on Flattop-Concrete Roof of Single-Room House with Lightweight-Concrete Walls as Constructed on Narrow Space in Bangkok
}

\author{
Pattana Suwansumrit ${ }^{1}$, Kasem Chunkao ${ }^{1}$, Surat Bualert ${ }^{1}$, Chulabut Chanthasoon ${ }^{2}$, Chatri Nimpee ${ }^{1}$, Noppawan \\ Semvimol $^{2}$, Sakonwan Mokatip ${ }^{2}$, Pongisara Rollap², Pavin Wichittrakarn² \& Manlika Srichomphu ${ }^{2}$ \\ ${ }^{1}$ Department of Environmental Science, Faculty of Environment, Kasetsart University, Bangkok, Thailand \\ ${ }^{2}$ The King's Royally Initiated Laem Phak Bia Environmental Research and Development Project, Chaipattana \\ Foundation, Thailand \\ Correspondence: Kasem Chunkao, Department of Environmental Science, Faculty of Environment, Kasetsart \\ University, Bangkok 10900, Thailand. Tel: 66-2579-2116. E-mail: prof.kasemc@gmail.com
}

$\begin{array}{lc}\text { Received: January 29, } 2015 & \text { Accepted: April 29, } 2015 \quad \text { Online Published: August 30, } 2015 \\ \text { doi:10.5539/mas.v9n9p92 } & \text { URL: http://dx.doi.org/10.5539/mas.v9n9p92 }\end{array}$

The research is financed by The King's Royally Initiated Laem Phak Bia Environmental Research and Development Project, Chaipattana Foundation.

\begin{abstract}
Growing greenery cover on flattop-concrete roof of single-room house with lightweight-concrete walls for lagging heat conduction was experimented during 10 August-30 November 2014 at Kasetsart University on narrow space between the College of Environment and car park buildings which emphasized on minimum room size of $2.5 \mathrm{~m}$ width, $2.5 \mathrm{~m}$ length, and $2.5 \mathrm{~m}$ height as declared by Building Control Act 1990. The methods of study were conducted by installing air thermometers at distance from the house and one meter above ground in northerly, southerly, easterly, westerly and flattop-concrete roof by alternating closing and opening the door and window. The research results found the maximum room temperature ranging $34.5-35.5{ }^{\circ} \mathrm{C}$ and minimum $26.5-27.7{ }^{\circ} \mathrm{C}$ for closing door and closing window, then decreasing almost being equal from degree of opening door and window, and clearly changing in conditions of long duration, high intensity, and often frequency of rainfall. Using Pudsaon or Cape Jasmine (Gardenia jasminoides J.Ellis) as grown in experimental pots containing coconut flake due to its characteristics of more consuming phreatophyte with high rate of using water for evapotranspiration process that can absorb surrounding heat through converting process to become latent heat flux. In consequence, room temperature was lowered down to $24.5^{\circ} \mathrm{C}$ and following by decreasing lag time from 2 hours to 0.5 hours, and also different lag time from 1-2 hours to 0.5-1.5 hours which were indicated better comfortable living. Closing both door and window or either one could not be conditioned for everyday lifestyle of people in dense and populated Bangkok city. In addition, construction of single-room house with flattop-concrete roof and lightweight-concrete walls were surely eligible to protect heat transferring from hot air outside into room rather than from room to outside, except opening both door and window at the same time
\end{abstract}

Keywords: heat conduction, urbanization, latent heat flux

\section{Introduction}

The population explosion has been spread out in the whole world that makes them struggling to find some place to live together with satisfying of income for well-being family. Inevitably, the natural resources have been occupied for human settlement, especially forest areas from lowlands to highlands. The economy of single family is gradually declined because of extended families and coinciding with the collapse of national economy pushing the family members to depart the community to find better job opportunity, mostly in the big cities (Ferreira \& Condessa, 2012; Vollmer \& Gret-Regamey, 2013; Abou-Korin, 2014; Meier \& Quium, 1991). According to such condition, the dwellers and accessory construction have to be unavoidably accomplished in order to accommodate those non-residents without any care for city planning that mostly happening in developing countries. Not only 
problems from solid wastes and wastewater have been evidently found but also another environmental problems such as noise, wastewater, air pollution and solids wastes which are not fascinated visualization, and hot climate (Li et al., 2009; Ward \& Peters, 2007; Kujinga et al., 2014).

Among aforesaid environmental problems, hot climate plays vital role in humid populated cities along with dense households, particularly the cities as located in the tropical zone that causing more hotter conditions that might be urban heat island (Takebayashi et al., 2014; Verma et al., 1978; Wolf et al., 2008). In general, the urban heat island is the area (municipal, urban, suburban and dense-populated community areas) to elevate temperature. It surrounds to the big and tall buildings, houses, shophouses, religious buildings, green roof, green patches, city parks, and ponds in which they play significant role in function on sources and sinks for day and night heat balance (Santamouris, 2014; Coseo \& Larsen, 2014; Botkin \& Keller, 2011; Chun \& Guldman, 2014; Honjo \& Takakura, 1990; Oke et al., 1991; Lokoshchenko, 2014; Santamouris, 2001; Maimaitiyiming et al., 2014). Ketterer \& Matzarakis (2014) found urban heat increasing temperature $0.3 \mathrm{~K}$ and $2 \mathrm{~K}$ and may be up to $12 \mathrm{~K}$ in the city concrete; $1.5-3.0^{\circ} \mathrm{C}$ per 100 years; building cooling energy use by Sun $\&$ Augenbroe $(2014) ; 1{ }^{\circ} \mathrm{C}$ to $5^{\circ} \mathrm{C}$ from air conditioning units by Coseo \& Larsen (2014); and average monthly $2.6^{\circ} \mathrm{C}$ in urban heat island by Shahidan et al (2012). There were a lot of research reports concerning with decreasing air temperature in heat island areas by either growing green patch or storage water ponds on which Skoulika et al (2014) found nocturnal cool islands varying $0.7 \mathrm{~K}$ to $2.8 \mathrm{~K}$ and daytime $0.2 \mathrm{~K}$ to $2.6 \mathrm{~K}$ from ambient temperature lower than $34{ }^{\circ} \mathrm{C}$, surface temperature decreasing $1.3{ }^{\circ} \mathrm{C}$ and also for every $10 \%$ increase in green area from the study of Coseo and Larsen (2014); 2.14 ${ }^{\circ} \mathrm{C}$ to $5.15^{\circ} \mathrm{C}$ together with increasing relative humidity $6.21 \%$ to $8.30 \%$ by Zhang et al $(2013), 0.1 \mathrm{~K}$ to $0.33 \mathrm{~K}$ per roof albedo increase by Santamouris (2014).

Bangkok is suited in the previous statement according to locate in hot and humid and tropical zone, and confronting with pollution problems, especially stream, air, and noise pollution. Although the Bangkok city planners spend an effort to deduct heat by growing green plants along the roadsides and road isles and also providing green belts for city parks and greenery patches on public areas. Unfortunately, it has been accepted as less usefulness due to not only ignoring to growing greenery plants on roadsides and road isles as the same as around the concrete wooden houses (small houses, shophouses, housing estates, shopping centers, medicare buildings) but also not planning green tree growing in all parts of the city. Nowadays, the it is hard to find out the wooden houses, only concrete buildings are replaced in all parts of Thailand and some other hot and humid countries, especially ASEAN countries. Expectedly, the room temperature has to be increased due to heat transfer (by conduction, convection, and radiation) from surroundings of the rooms, houses, and buildings that received direct radiation from the sun and sky. Reduction of transferred heat from outside houses is the basic concept to keep in-house temperature preferability for sustainable livelihood. It is remarkable to protect heat transfer from outside surroundings through four-side house wall panels (room wall panels) and roof that may be relieved by using insulated walls for heat reduction by conduction, evapotranspiration water (plants, soils, water body) by convection process, and blackbodies for heat absorption to all wavelengths by radiation or re-radiation process from sun and surroundings as shown in Figure 1.
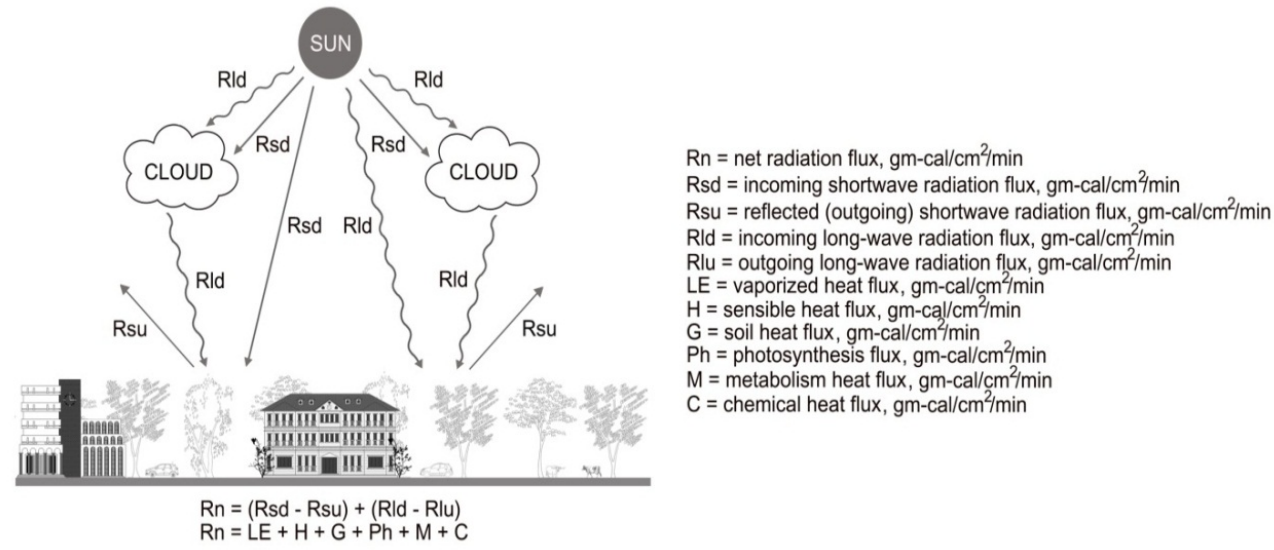

Figure 1. Incoming and outgoing solar radiation by means of electromagnetic waves to provide net radiation on the earth surface before transferring through constructed-insulated materials for deducting in-house temperature

Naturally, the sun radiates both incoming shortwave radiation (Rsd) and incoming long-wave radiation (Rld) to 
the earth surface approximately $1.94 \mathrm{~g}-\mathrm{cal} / \mathrm{cm}^{2} / \mathrm{min}$ (Sellers, 1965). Actually, incoming shortwave radiation (wavelength less than 4 microns) is composed of gramma rays, X-rays, ultraviolet, visible light, and near infrared on which they are directly reflected to the sky (Rsu), while both Rsd and Rld as heat transferring to the earth surface, then transferring to aky in form of outgoing long-wave radiation (Rlu) as described by Bowen (1926), Gates (1965; 1980), Hartman (1994), Chunkao (1971; 1979), Savage et al (2009), Holland et al (2013), Perez et al (1999), and Dicken et al (2013), in which the net radiation can be specified from above statement as following

$$
\mathrm{Rn}=(\mathrm{Rsd}+\mathrm{Rld})-(\mathrm{Rsu}+\mathrm{Rlu})
$$

On the other hand, Rn as obtained heat from solar radiation is utilized for latent heat flux (LE), sensible heat flux $(\mathrm{H})$, soil heat flux $(\mathrm{G})$, photosynthesis flux $(\mathrm{Ph})$, metabolism heat flux $(\mathrm{M})$, and chemical heat flux $(\mathrm{C})$ as identified by Gates $(1965 ; 1980)$, Chunkao $(1971 ; 1979)$ and presented in heat balance as

$$
\mathrm{Rn}=\mathrm{LE}+\mathrm{H}+\mathrm{G}+\mathrm{Ph}+\mathrm{M}+\mathrm{C} .
$$

From the explanation of Gates (1965; 1980), Dicken et al (2013), and Hartman (1994), the amount of Ph, M, C are very small amount in comparison with the earth surface receiving from the sun. Then they can be omitted from the equation (2) and can be rewritten as

$$
\mathrm{Rn}=\mathrm{LE}+\mathrm{H}+\mathrm{G}
$$

The $\mathrm{G}$ value, is referred to mainly heat transfer by conduction, in more positive than negative on daytime but almost negative on night time, but more or less zero for all-day period ( 24 hours). Even $\mathrm{G}$ is still positive, it has to heat the air through heat transfer process by either conduction, convection or radiation but it is provided very small part of heat transfer (Chunkao, 1971; 1979; Hartman, 1994; Holland et al., 2013; Bowen, 1926; Perez et al., 1999; Savage et al., 2009; Ashktorab et al., 1989; Sellers, 1965; Coseo \& Larsen, 2014; Dicken et al., 2013; Geiger, 2003). So G in equation (2) and (3) can be omitted in equation (4) as followings

$$
\mathrm{Rn}=\mathrm{LE}+\mathrm{H}
$$

It is noted here that the objects, plants and animals, households, buildings, shophouses, and others are mainly received from $\mathrm{LE}$ and $\mathrm{H}$. If water and plants are available, the heat on the earth surface can be utilized for LE, and $\mathrm{H}$ becomes less. In contrary, when there is no available water and plants, the earth surface heat has to utilize to heat air as sensible heat $(\mathrm{H})$ which is the most important heat to make high temperature outside buildings, and also inside building after heat transferring through the walls (Zhang et al., 2013; Sun \& Augenbroe, 2014; Shahidan et al., 2012; Ketterer \& Matzarakis, 2014; Santamouris, 2001; Oke et al., 1991; Lokoshchenko, 2014; Honjo \& Takakura, 1990; Chun \& Guldmann, 2014; Maimaitiyiming et al., 2014; Santamouris, 2014). As stated before, the architects have tried to look for insulated materials for cooling inside buildings and households due to deducting transferred heat from outside buildings and households but depending on types of insulated materials. Besides, the study is not only concentrated on types of insulated materials but also the thickness of insulated materials (including plant species growing) for wall panel construction has to be focused on in-house temperature deduction.

Recently, the scientist found the method for deducting heat conduction by using lightweight concrete walls for room, house, and building construction in order to make room temperature preferable and comfortable due to lower air bubbles inside it. Actually, the raw materials of lightweight concrete blocks (using no aggregate larger than sand) are composed of cement, lime, sand, Gypsum, Aluminum powder, and water together with giving space for air bubble that might be approximately up to $50 \%$ of lightweight concrete block. In principles, the thermal conductivity plays a significant role in heat transferring from the hotter to the colder temperature passing through the wall panels as constructed by lightweight concrete (Sellers, 1965; Coseo \& Larsen, 2014; Shahidan et al., 2012; Geiger, 2003; Gates, 1965; Hartman, 1994; Maimaitiyiming et al., 2014; Santamouris, 2014). However, the value $\mathrm{k}$ (thermal conductivity) is depended on the portion of raw materials of lightweight concrete blocks, particularly the amount of cement, lime, and quartz sand on which they are existed higher density and thermal conductivity values. Normally, the lightweight concrete block is pertained the gross dry density 0.45 $\mathrm{g} / \mathrm{cc}$ to $0.85 \mathrm{~g} / \mathrm{cc}$, and thermal conductivity less than $1.0 \mathrm{cal} / \mathrm{cm}^{2} /{ }^{\circ} \mathrm{C} / \mathrm{min}$ (Sellers, 1965; Geiger, 2003; Gates, 1965; 1980; Chunkao, 1979; Savage et al., 2009; Dicken et al., 2013).

Giving greenery cover and tree planting in urban areas have been suggested by Mangone \& Linden (2014), Akbari et al (1992), McPherson (1988), McPherson \& Rowntree (1993), McPherson \& Simpson (2003), Coseo \& Larsen (2014), Zhang et al (2013), Honjo \& Takakura (1990), Alchapar et al (2014), Oke et al (1991), 
Shahidan et al (2012) while Chun \& Guldmann (2014) to introduce the roof-top green cover and water areas as well as giving vegetative courtyard and city parks to deduct urban temperature by Mangone \& Linden (2014), Skoulika et al (2014), McPherson (1988), Takebayashi et al (2014) and $\mathrm{Ng}$ et al (2012); and also making higher reflecting roof by Alchapar et al (2014). Theoretically, an incoming heat protection by tree planting, pond construction, green patches around the cities or houses, and green-top-roof buildings in urban heat island would be the most important to reduct ambient air temperature due to make them away from exactly sources and sink in heat transfer by re-radiation and heat absorption before re-radiation taking place (Gates, 1965; 1980; Hartman, 1994; Geiger, 2003; Perez et al., 1999; Chunkao, 1979; Bowen 1926). Intentionally, they are the cooling processes concerning in decreasing rather than heating ambient air temperature before heat transferring through the insulated materials herein lightweight concrete blocks and growing tree around houses/rooms, dwellers, and buildings (Sellers, 1965; Akbari et al., 1992; Alchapar et al., 2014; Heilman \& Brittin, 1989; Skoulika et al., 2014; Lee et al., 2004; Deacon, 1949; Takebayashi et al 2014). In other words, built houses and buildings should be used lightweight concrete blocks for reducing heat transferring by decreasing the thermal conductivity in order to live with cool temperature. Truly speaking, the houses and buildings wish to grow trees around them, it could be made cooler temperature inside them for more convenience and comfort with high energizing routine works (McPherson, 1988; McPherson \& Rowntree, 1993; McPherson \& Simpson, 2003; Garratt, 1978; Ng et al., 2012; Mangone \& Linden, 2014).

As mentioned before, this study is aimed to find the insulated materials to reduce heat transfer between objects of differing temperature in thermal contact in which it can be achieved with specially engineering method concerning with suitable types of insulated materials and its insulation capacity (thermal conductivity). Theoretically, heat is defined as the transfer of thermal energy across a well-defined boundary around a thermodynamic system, while heat transfer is a process of thermal energy across the object to another environment. Actually, there are 3 processes of heat transfer: firstly, conduction is the process of heat transfer between hot-temperature object through thermal conductivity to the cool-temperature environment; secondly, convection is a process of heat transfer to its environment by motion of fluid molecules; and thirdly, radiation is the process of heat transfer from the movement of charge particles within atoms converting to electromagnetic radiation (Deacon, 1949; Lee et al., 2004; Gates, 1965; 1980; Sellers, 1965; Geiger, 2003; Chunkao, 1979; Ashktorab et al., 1989; Bowen, 1926; Sun \& Augenbroe, 2014; Zhang et al., 2013; Coseo \& Larsen, 2014; Lokoshchenko, 2014; Honjo \& Takakura, 1990; Oke et al., 1991).

However, the thermal conductivity plays role in heat conductive transfer in which the Fourier's law of heat transfer have been applied Fourier's la of heat conduction by Sellers (1965), Chunkao (1979), Gates (1965; 1980), and Hartman (1994) in the content of the law of heat conduction states that the time rate of heat transfer through a material is proportional to the negative gradient in temperature and to the area at right angle to that gradient, through which the heat flows with the rate of $\mathrm{Q} / \mathrm{t}(\mathrm{cal} / \mathrm{cm} / \mathrm{sec})$, It can be illustrated in equation (5) and showed the hypothetical views in Figure 2.

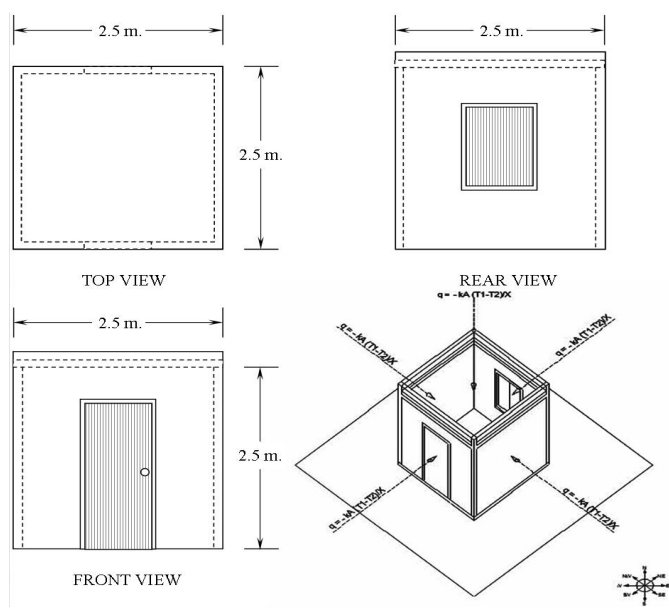

Figure 2. Hypothetical illustration Fourier's law of transferring heat conduction from higher-temperature to cooler-temperature objects at right angle to the temperature gradient

$$
\mathrm{Q} / \mathrm{t}=-\mathrm{kA}\left(\mathrm{T}_{1}-\mathrm{T}_{2}\right) / \mathrm{X}
$$


Where Q ir represented for heat transfer $\left(\mathrm{cal} / \mathrm{cm}^{2}\right), \mathrm{kfor}$ thermal conductivity $\left(\mathrm{cal} / \mathrm{cm}^{2} / \mathrm{sec} /{ }^{\circ} \mathrm{C}\right), \mathrm{A}$ for surface area $\left(\mathrm{cm}^{2}\right), \mathrm{T}_{1}$ for outside-hot temperature $\left({ }^{\circ} \mathrm{C}\right), \mathrm{T}_{2}$ for inside-cold temperature $\left({ }^{\circ} \mathrm{C}\right), \mathrm{X}$ for thickness of insulated material $(\mathrm{cm}), \mathrm{t}$ for time taken $(\mathrm{sec})$ and $\mathrm{q}$ for heat flow rate through thickness $\mathrm{X}(\mathrm{cal} / \mathrm{cm} / \mathrm{sec})$

According to vary $\mathrm{X}$ (thickness) of materialized surface area which is functioned as thermal conductivity, then the equation (6) can be rewritten as

$$
\mathrm{q}=-\mathrm{kA}\left(\mathrm{T}_{1}-\mathrm{T}_{2}\right) / \mathrm{X}
$$

$T_{1}$ is supposed to be hot temperature (temperature of surrounding environment) due to radiative heat transfer from direct solar radiation at daytime. If $\mathrm{T}_{2}$ in equation (6) is the appropriate temperature for human life, then $\mathrm{T}_{2}$ can be replaced by $25^{\circ} \mathrm{C}$ which will be presented as:

$$
\mathrm{X}=-\mathrm{kA}\left(\mathrm{T}_{1}-25\right) / \mathrm{q}
$$

Actually $\mathrm{X}$ (thickness of insulated material) is used for this experiment on $2.5 \mathrm{~cm}$ for reduction of heat transfer (q) from $T_{1}$ point to the $T_{2}$ point through thermal conductivity with cross sectional area A. So, the equation (7) can be expressed below:

$$
\mathrm{q}=-(\mathrm{kA})\left(\mathrm{T}_{1}-\mathrm{T}_{2}\right) / \mathrm{X}
$$

In case of expressing the heat transfer per unit area, then the equation (4) becoming to equation (8) as following:

$$
\mathrm{Q} / \mathrm{t}=-(\mathrm{kA})\left(\mathrm{T}_{1}-\mathrm{T}_{2}\right) / \mathrm{X}
$$

If $t$ is fixed, then $T_{1}$ is varied from place to place, the same as fixed $T_{2}$ value, and taking $t$ (time) is varied. Then after, the relationships between $\mathrm{Q}$ and $\mathrm{T}_{1}$ can do the same as $\mathrm{Q}$ and $\mathrm{t}$ relation. Because of aforesaid statement, those relations can be graphically constructed in which the proper $t$ (time taken) and proper $T_{1}$ (temperature of applicable location) can be calculated in order to determine the thickness of specific insulated materials.

Accordance with evapotranspiration process is basic concept for taking away by convective heat transfer in terms of latent heat flux by water use for evapotranspiration (Gates, 1965; 1980; Chunkao, 1971; Holland et al., 2013; Bowen, 1926) which can be presented in equation (10) as following

$$
\mathrm{Q}=\mathrm{LE}(\mathrm{t})
$$

Where $\mathrm{Q}=$ convective heat transfer $(\mathrm{cal})$

$\mathrm{L}=$ latent heat of vaporization $(583 \mathrm{cal} / \mathrm{g})$

$\mathrm{E}=$ evapotranspiration $\left(\mathrm{g} / \mathrm{cm}^{2} / \mathrm{sec}\right),(\mathrm{L} \times$ Evaporated water $)$

$\mathrm{t}=$ time taken $(\mathrm{sec})$

Due to $\mathrm{E}$ is escaped from the horizontal surface, the convective heat transfer can be presented in equation (11)

$$
\mathrm{Q}=\mathrm{kA}\left(\mathrm{T}_{1}-\mathrm{T}_{2}\right)(\mathrm{t})
$$

Where $\mathrm{Q}$ is represented for convective heat transfer (cal), $\mathrm{k}$ for heat transfer coefficient $\left(\mathrm{cal} / \mathrm{cm}^{2} /{ }^{\circ} \mathrm{C} / \mathrm{sec}\right)$, A for transfer surface $\left(\mathrm{cm}^{2}\right), T_{1}$ for temperature of environment $(\mathrm{K}), \mathrm{T}_{2}$ for temperature in house/room/ building (K) and $\mathrm{t}$ for time taken $(\mathrm{sec})$

The above statements had been afforded to describe the heating phenomena from direct and indirect solar radiation on earth surface that caused high in-house and outside temperature as the main heating sources. By such condition, it brings to concentrate in this research which aims to focus on using lightweight concrete blocks as thermal conductivity. If is not effective to deduct the in-room, in-house, and in-building temperature by using growing trees/plants to absorb heat from surrounding environment by heat transfer processes not only conduction and convection, but it is still included the radiation processes.

Normally, the comfortable room temperature for Thais, especially in summer and wet period, should be around $26^{\circ} \mathrm{C}$ $32{ }^{\circ} \mathrm{C}$ along with well ventilation. So, the old-style architectural design was open walls and space under a Thai house styles in order to keep comfortable the room temperature by self-ventilation. Later on the Thai house model has been changed by influences of Indochina and European styles of both the construction materials and forms with less ventilation and requiring air conditioners. Anyhow, the Building Control Act 1990 is comprised of the smallest room of building or houses must not be less than $2.5-\mathrm{m}$ width $\times 2.5-\mathrm{m}$ length $\times 2.5-\mathrm{m}$ height in order to provide well ventilation for the case of no air conditioner available. To make clear understanding, the greenery house-cover concept was applied to absorbing heat from outside before transferring through the house walls which are low thermal 
conductivity.

\section{Methods and Procedure}

\subsection{Installing Thermometers and Greenery Experimental Pots}

\subsubsection{Localization of Temperature Measurement}

The $15.625 \mathrm{~m}^{2}$ room was the minimum size by obligation declaration which was chosen to study on the out-sort heat transfer through thermal conductivity of lightweight concrete in order to keep its comfortable temperature for everyday living. The experimental lightweight-concrete house was designed for ventilation by making in wooden window $(0.75 \times 0.5 \mathrm{~m})$ and glass-iron-frame door $(2.5 \times 0.5 \mathrm{~m})$ while flattop roof $(2.5 \times 2.5 \mathrm{~m})$ was made of concrete with stone:sand:cement ratio equivalent to 1:2: 5 was built without any leakage. The four automatic-electric-digital thermometers were installed about 1-m height from the asphalt-concrete ground surface along with 0.5 meter from four directions of lightweight-concrete walls and another one on the flattop-concrete roof about 1-m height as illustrated in Figure 3. For period of experiments, the research on growing greenery cover on flattop-concrete roof of single-room house with lightweight-concrete walls for deducting heat conduction as constructed on narrow space was conducted inside Kasetsart University on narrow space between the College of Environment and car park buildings in dense-populated city of Bangkok, Thailand during 10 August - 30 November 2014.
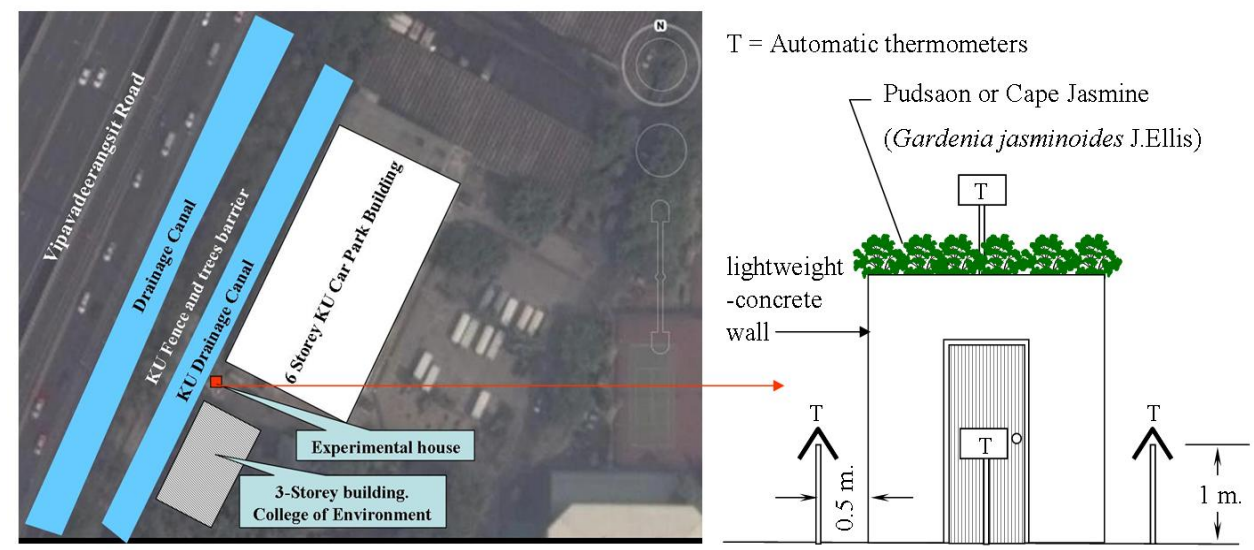

Figure 3. Well equipping automatic thermometers on 1-m height above earth surface and 0.5-m far from all 4 lightweight-concrete wall4 of experimental house as located on asphalt-concrete ground floor between College of Environment and KU car-park buildings,and also at 1-m height above the flattop-concrete roof with planting Pudsaon or Cape Jasmine (Gardenia jasminoiddes J.Ellis) for three-consecutive-day temperature recording

\subsubsection{Pretest of Feasible Latent Heat Flux}

The pretest was conducted on 5 plots each of growing plants and controls in order to compare the amount of water used through the evapotranspiration process which can be converted to plant absorbed latent heat flux from the flattop-concrete roof before conducting into the lightweight-concrete-wall house. The five-experiment and five-control pots were placed on the asphalt concrete ground floor which was located on the narrow space between College of Environment and car-park buildings in the west perimeters of Kasesart University campus as 5 illustrated in Figure 2.

\subsubsection{Settling Greenery Plots on Experimental Flattop-Concrete Roof}

According to flattop-concrete roof of single-room house, the 36 plots containing humus soils for growing Pudsaon or Cape jasmine (Gardenia jasminoides J.Ellis) in pot containing coconut flake with 60-cm height were designated the position to lay down them from beginning of experiments until research accomplishing as seen in Figure 2 . LE was determined by multiplying evaporated water and latent heat of vaporization.

\subsection{Cases of Temperature Measurement}

As stated before, the Building Control Act 1990 is comprised of the smallest room of building or houses must not be less than 2.5-m width $\times 2.5-\mathrm{m}$ length $\times$ 2.5-m height (the worst case of minimum-room size) in order to provide well ventilation and less heat storage, in case of no air conditioner available. For understanding, the concept of greenery cover on flattop-concrete roof of such a worse-case-house room size was applied to absorbing heat from 
outside before piercing through the house walls which are low thermal conductivity. In addition, the lightweight concrete have been brought to build the house, shophouse, and buildings for decreasing its room temperature by measuring at $1-\mathrm{m}$ height above the asphalt-concrete ground floors with $0.5-\mathrm{m}$ far from all 4 -wall sides (as located between College of Environment and KU car-park buildings) and on the flattop-concrete roof for 3 -day-consecutive period without greenery and with greenery covers for 4 cases such as Case 1: close the window and close the door; Case 2: open the window and close the door; Case 3: close the window and open the door; and Case 4: open the window and open the door. The air temperature at four-outside wall temperature including upper flattop-concrete roof temperature and inside-room temperature were recorded on the sampling dates in wet/rainy, cold weather, and winter periods

\subsection{Flattop-Concrete Roof Greenery for Room Temperature Deduction}

The flat-top concrete roof was fully covered with the green plant as grown in pot units together with watering every morning. The losses of water weight in the whole flat-top roof were converted to heat of vaporization (LE) which could be supposed to be the deduction heat in the room

Due to the experimental lightweight-concrete room as constructed with the minimum size which is declared by laws that might not be comfortable to human living but the expected result has intended to obtain some idea for cooling room temperature by employing the greenery either cover on flattop-concrete room for applying in constructing small concrete houses in dense and populated city. Furthermore, this research may be not provided the final outcome but it is still needed another research work is really needed to solve the problem on warming room temperature with the minimum size by using lightweight concrete as insulator. However, it is expected to obtain from this research in terms of guideline for employing the insulator and also the improvement of room size limiting for comfortably living in the future.

\section{Results and Discussion}

\subsection{Temperature Variation in Lightweight-Concrete Room}

After 12-day experiments, the results found little change in total average inside room temperature to all four cases such as $29.66{ }^{\circ} \mathrm{C}$ for closed door-closed window (CDCW), $29.40{ }^{\circ} \mathrm{C}$ for open door-closed window (ODCW), $28.70{ }^{\circ} \mathrm{C}$ for closed door-open window (CDOP), and $28.40^{\circ} \mathrm{C}$ for open door-open window (ODOW) as shown in Table 1, but the CDCW case was revealed the highest temperature because there was no ventilation for taking out some reradiating heat energy to outside, meanwhile heat conduction from outside transmitting continuously through four sides of lightweight-concrete walls (Alchapar et al 2014, Akbari et al 1992, Dicken et al 2013). At the same time, the daytime temperature found in the ranges of $27.26-33.00{ }^{\circ} \mathrm{C}$ for $\mathrm{CDCW}$, 26.92-30.77 ${ }^{\circ} \mathrm{C}$ for ODCW, 27.31-32.00 ${ }^{\circ} \mathrm{C}$ for CDOW, and 27.29-31.37 ${ }^{\circ} \mathrm{C}$ for ODOW (see Table 1) on which they did not show clearly changes from one to the others but $\mathrm{CDCW}$ lightweight-concrete room was indicated somewhat cooler than the others due to higher outside temperature (flattop-concrete roof and four-side measuring points) and heat reradiating from car-park and Environmental buildings (Sellers, 1965; Takebayashi et al., 2014; Oke et al., 1991; Botkin \& Keller, 2011; Gates, 1965).

Taking four-outside temperature for 12-consecutive days of experiments in consideration, the total average temperature found $29.17^{\circ} \mathrm{C}, 28.78{ }^{\circ} \mathrm{C}, 29.29^{\circ} \mathrm{C}$, and $29.04{ }^{\circ} \mathrm{C}$ for the measuring days of $\mathrm{CDCW}, \mathrm{ODCW}, \mathrm{CDOW}$, and ODOW, respectively (see Table 1). It would be pointed out that the degrees of outside temperature were the same all 12-day experiments. In the same manner, the ranges of at daytime were equivalent to $28.47-31.57{ }^{\circ} \mathrm{C}$, 27.99-30.77 ${ }^{\circ} \mathrm{C}, 28.59-31.70{ }^{\circ} \mathrm{C}$, and $28.67-31.34{ }^{\circ} \mathrm{C}$ for CDCW, ODCW, CDOW, and OCOW, respectively, and also still more or less equivalent to each other. Moreover, their night temperature did not vary in wide ranges but the temperature values were accepted as the same group. Furthermore, the temperature values on flattop-concrete roof were found the ranges on day time $28.67-31.83{ }^{\circ} \mathrm{C}, 27.88-30.95{ }^{\circ} \mathrm{C}, 28.83-32.33{ }^{\circ} \mathrm{C}$, and $28.89-31.89{ }^{\circ} \mathrm{C}$ as received during doing researches on respective activities of $\mathrm{CDCW}$, ODCW, $\mathrm{CDOW}$, and ODOW which were the same as measuring night time temperature of $27.75-29.63{ }^{\circ} \mathrm{C}, 27.06-29.75{ }^{\circ} \mathrm{C}, 27.49-29.79{ }^{\circ} \mathrm{C}$, and 27.26-29.24 ${ }^{\circ} \mathrm{C}$, respectively (Table 1 ).

In other words, the $\mathrm{CDCW}$ room temperature was found the average at daytime $30.13{ }^{\circ} \mathrm{C}$ and nighttime $29.20^{\circ} \mathrm{C}$ (total average $29.66{ }^{\circ} \mathrm{C}$ ), while ODCW $30.11{ }^{\circ} \mathrm{C}$ at daytime and $28.18{ }^{\circ} \mathrm{C}$ at nighttime (total average $28.78{ }^{\circ} \mathrm{C}$ ), CDOW $30.67{ }^{\circ} \mathrm{C}$ at daytime and $28.20^{\circ} \mathrm{C}$ at nighttime (total average $29.43{ }^{\circ} \mathrm{C}$ ), ODOW $30.17^{\circ} \mathrm{C}$ at daytime and $28.09^{\circ} \mathrm{C}$ at nighttime (total average $29.23{ }^{\circ} \mathrm{C}$ ). The highlight was focused on open either door or window and both of them which highlighted on decreasing temperature from CDCW $29.66^{\circ} \mathrm{C}$ to $0.88{ }^{\circ} \mathrm{C}$ for ODCW, $0.23{ }^{\circ} \mathrm{C}$ for CDOW, and $0.43{ }^{\circ} \mathrm{C}$ for ODOW (ranging $0.23{ }^{\circ} \mathrm{C}$ to $0.43{ }^{\circ} \mathrm{C}$ ). It was not surprised on decreasing temperature by either opening door or window and both at daytime due to heat energy around the room and outer space that could be conveniently transferred inside room through opening door or window and both. It is remarkable to 
point out that the decreasing temperature from $\mathrm{CDCW} 29.20{ }^{\circ} \mathrm{C}$ by either opening door or window and both found $1.02{ }^{\circ} \mathrm{C}$ for ODCW, $1.00{ }^{\circ} \mathrm{C}$ for $\mathrm{CDOW}$, and $1.1{ }^{\circ} \mathrm{C}$ for ODOW (ranging $1.00{ }^{\circ} \mathrm{C}$ to $1.11{ }^{\circ} \mathrm{C}$ ). It would be interpreted that even outside temperature at nighttime was cooler than inside room, the single door and window or both were not big enough to translocate into room. There were three reasons: firstly the room temperature was still high enough to be replaced by cool air from outer space; secondly, lightweight-concrete walls could be translocated in and out room due to low heat conductivity; thirdly, daytime heat storage in flattop-concrete ceiling could be continuously reradiated down to room that make it cooler (Gates, 1965; Chunkao, 1971; Garratt, 1978; Hartman, 1994; Lee et al., 2004; Lokoshchenko, 2014; Meier \& Quium, 1991; Ng et al., 2012; Perez et al., 1999; Sellers, 1965; Sun \& Augenbroe, 2014; Verma et al., 1978; Bowen, 1926; Coseo \& Larsen, 2014)

Table 1. Averaged and ranged temperature of flattop-concrete-roof room with lightweight-concrete walls for three-day consecutive measurement

\begin{tabular}{|c|c|c|c|c|c|c|c|c|c|c|c|c|c|}
\hline \multirow{3}{*}{ Day } & \multirow{3}{*}{ Time } & \multicolumn{3}{|c|}{1} & \multicolumn{3}{|c|}{2} & \multicolumn{3}{|c|}{3} & \multicolumn{3}{|c|}{4} \\
\hline & & \multicolumn{3}{|c|}{ Closed Door-Closed Window } & \multicolumn{3}{|c|}{ Opened Door-Closed Window } & \multicolumn{3}{|c|}{ Closed Door-Opened Window } & \multicolumn{3}{|c|}{ Opened Door-Opened Window } \\
\hline & & Inside & Avg.OUT & roof & Inside & Avg.OUT & roof & Inside & Avg.OUT & roof & Inside & Avg.OUT & roof \\
\hline 1 & $12: 00-18: 00$ & 34.44 & 32.74 & 33.04 & 27.00 & 26.64 & 26.97 & 32.90 & 32.71 & 33.32 & 32.31 & 32.02 & 32.67 \\
\hline 1 & $18: 00-24: 00$ & 32.67 & 29.84 & 30.04 & 26.91 & 27.42 & 27.65 & 30.43 & 30.19 & 30.64 & 28.62 & 28.29 & 28.61 \\
\hline 1 & 00:00-06:00 & 29.46 & 28.35 & 28.60 & 25.96 & 26.47 & 26.72 & 28.05 & 27.88 & 28.07 & 26.71 & 26.48 & 26.68 \\
\hline 1 & 06:00-12:00 & 28.51 & 30.06 & 30.57 & 29.30 & 29.87 & 29.83 & 29.60 & 29.73 & 29.85 & 29.01 & 28.63 & 28.78 \\
\hline 2 & $12: 00-18: 00$ & 32.81 & 31.92 & 31.99 & 31.98 & 31.68 & 32.06 & 31.77 & 31.35 & 31.95 & 31.12 & 31.10 & 31.74 \\
\hline 2 & $18: 00-24: 00$ & 31.16 & 27.40 & 27.48 & 29.67 & 28.80 & 29.04 & 27.55 & 26.53 & 26.58 & 29.87 & 29.51 & 29.76 \\
\hline 2 & 00:00-06:00 & 27.21 & 26.94 & 27.22 & 28.03 & 27.88 & 28.08 & 26.32 & 26.51 & 26.68 & 28.17 & 28.03 & 28.21 \\
\hline 2 & $06: 00-12: 00$ & 26.75 & 29.50 & 30.06 & 30.13 & 30.26 & 30.44 & 28.86 & 29.26 & 29.51 & 30.01 & 29.79 & 29.99 \\
\hline 3 & $12: 00-18: 00$ & 31.74 & 30.04 & 30.45 & 33.32 & 33.29 & 33.82 & 31.32 & 31.08 & 31.72 & 30.66 & 30.91 & 31.27 \\
\hline 3 & $18: 00-24: 00$ & 28.24 & 28.19 & 28.50 & 27.40 & 26.65 & 26.96 & 29.31 & 29.06 & 29.28 & 28.44 & 28.21 & 28.32 \\
\hline 3 & 00:00-06:00 & 26.44 & 27.23 & 27.44 & 26.77 & 26.32 & 26.38 & 27.57 & 27.45 & 27.71 & 26.72 & 26.74 & 26.91 \\
\hline 3 & $06: 00-12: 00$ & 26.52 & 27.90 & 28.27 & 28.90 & 28.94 & 28.97 & 29.55 & 29.77 & 30.00 & 29.09 & 28.82 & 28.96 \\
\hline \multicolumn{2}{|c|}{ Ave. 12:00-18:00 } & 33.00 & 31.57 & 31.83 & 30.77 & 30.54 & 30.95 & 32.00 & 31.71 & 32.33 & 31.37 & 31.34 & 31.89 \\
\hline \multicolumn{2}{|c|}{ Ave. 18:00-24:00 } & 30.69 & 28.47 & 28.67 & 27.99 & 27.62 & 27.88 & 29.09 & 28.59 & 28.83 & 28.97 & 28.67 & 28.89 \\
\hline \multicolumn{2}{|c|}{ Ave. 00:00-06:00 } & 27.70 & 27.50 & 27.75 & 26.92 & 26.89 & 27.06 & 27.31 & 27.28 & 27.49 & 27.20 & 27.08 & 27.26 \\
\hline \multicolumn{2}{|c|}{ Ave. 06:00-12:00 } & 27.26 & 29.16 & 29.63 & 29.44 & 29.69 & 29.75 & 29.33 & 29.59 & 29.79 & 29.37 & 29.08 & 29.24 \\
\hline \multicolumn{2}{|c|}{ Total Average. } & 29.66 & 29.17 & 29.47 & 28.78 & 28.68 & 28.91 & 29.43 & 29.29 & 29.61 & 29.23 & 29.04 & 29.32 \\
\hline
\end{tabular}

The above results found that the inside temperature in small, flat-topped concrete roof and lightweight-concrete room was exactly found higher than outer space and upper roof, no matter of doing activities by CDCW, ODCW, CDOW, and ODOW or not. Room ventilation plays a significant role in reradiating heat from lightweight-concrete walls and flattop-concrete roof ceiling continuously releasing that made the room warming and also some conducting heat from outside could be another cause for encouraging room warming as well. Room operation activity in terms of either Opening the door or opening window or both would be supported to head energy releasing to outer space. Deduction of heat energy transferring from reradiating objects surrounding the lightweight-concrete walls (low heat conductivity) and flattop-concrete roof would be better way to conduct by using green plants for absorbing sensible heat to convert to latent heat. However, an existence of buildings in northerly and southerly and including water body in KU canal westerly are surrounded the experimental unit causing the reradiating heat energy moving back and forth in this limited open space. This would be another factor involving with low translocation rate outside heat energy to room space that called as longer lag time (Garratt, 1978; Hartman, 1994; Lee et al., 2004; Lokoshchenko, 2014; Mcpherson \& Rowntree, 1993; Meier \& Quium, 1991; Ng et al., 2012; Perez et al., 1999; Santamouris, 2014; Sellers, 1965; Sun \& Augenbroe, 2014; Verma et al., 1978; Gates, 1965; 1980; Geiger et al., 2003; Bowen, 1926; Deacon,1949; Coseo \& Larsen, 2014).

\subsection{Lag Time Temperature}

The field measurement under the $\mathrm{CDCW}$ room operation activity found the nighttime temperature ranging 26.44-32.67 ${ }^{\circ} \mathrm{C}$ and daytime temperature ranging 26.52-34.44 ${ }^{\circ} \mathrm{C}$ (see Table 1)except during rain falling, temperature slowing down to $24.50{ }^{\circ} \mathrm{C}$ for minimum and $33.50{ }^{\circ} \mathrm{C}$ for maximum as illustrated in Figure 4a. When the air temperature was tending to increase, the $\mathrm{CDCW}$ room temperature also was followed the same trend with highlighting the lag time until it reached at the maximum point with showing lag time. Then, the room temperature was gradually decreased after air temperature decreased Figure 4a). In other words, the lag time at maximum room temperature was about 4-7 hours (averaging 5.5 hours) while minimum temperature found between $2-5$ hours (averaging 3.5 hours) due to more heat storage. This condition is normally higher temperature 
due to re-radiation from surrounding buildings and other objects. In addition, an increasing the amount and duration of rainfall as well as its intensity and frequency are usually paid vital role in increase of lag time between air and room temperature because of low heat conductivity of lightweight-concrete walls to transmit into room (Alchapar et al., 2014; Chun \& Guldmann, 2014; Skoulika et al., 2014; Akbari et al., 1992; Sellers, 1965). The said condition could make the lag difference in both the maximum and minimum temperature about 2 hours owning to low heat conductivity of lightweight-concrete walls. In reality, rainfall was influenced on room temperature according to high heat conductivity of the flattop-concrete roof. Summarily speaking, the time for comfortable living in this size of small room was short about 2 hours, except in raining condition that could be prolonged lag-time temperature in ranging 1-2 hours but it depended on rainfall duration and cool air temperature (Sellers, 1965; Deacon, 1949; Geiger et al., 2003; Arneth \& Stichlmair, 2001; Hartman, 1994).

CDOW room was enhanced the air circulation between outside and inside temperature which caused to make the lag time becoming 3-6 hours (averaging 4.5 hours) at maximum air temperature for warmer temperature of daytime and 2-4 hours (averaging 3 hours) for minimum temperature of nighttime. The lag time difference between the daytime maximum temperature and nighttime temperature of room was resulted 1.5 hours due to hot and cool air circulation process from opening door and closing window. This would be said that high frequency of rainfall was often occurred for three-day consecutive measurement, the lag time between air and room temperature was found longer period at both the maximum and minimum temperature for both opening door and closing window condition (see Figure $4 \mathrm{~b}$ ) that made some cooler air circulating into room by ventilation process. Obviously, only opening door caused the lag time difference between maximum and minimum room temperature was indicated about 1.5 hours. It would be remarked that not only influence of rainfall to decrease room temperature but also opening the door was another factor to involve with circulating cooler air from inside that against decreasing room temperature (Alchapar et al., 2014; Botkin \& Keller, 2011; Chunkao, 1979; Chun \& Guldmann, 2014).

When the case of closing door and opening window (CDOW) was studied on looking the trend of inside and outside room temperature, the lag time found about 3-6 hours (averaging 4.5 hours) for daytime maximum temperature and 2-4 hours (averaging 3 hours) for nighttime minimum temperature. The lag time difference was 1.5 hours (more or less the condition of opening door and closing window) due to opening window encouraging more air ventilation. Remarkably, showering and rain falling were still paid vital role in decreasing lag time by making all-temperature lines overlapping as seen in Figure 4c. It would be emphasized that long-duration rainfall was exactly insisted to influence with gradually cooling room temperature because of low thermal conductivity of lightweight concrete (Gates, 1965; 1980; Geiger, 2003; Hartman, 1994; Ketterer \& Matzarakis, 2014: Honjo \& Takakura, 1990-1991) as shown in Figure 4b and 4c.

After ODOW experiments, the findings of all measuring points of both outside and room temperature were overlapped into one line as indicated in Figure 4d that made of lag time becoming 2-5 hours (averaging 3.5 hours) for daytime maximum temperature and 1-4 hours (averaging 2.5 hours) for nighttime minimum temperature due to well mixing between air and room temperature (see Figure 4d). The difference of lag time between minimum and maximum room temperature was resulted about 1 hour.

The flattop-concrete roof temperature would be rather higher than the another 4-point ground temperature because of roof concrete re-radiation as accumulated from direct solar radiation (Sellers, 1965; Wolf et al., 2008; Zhang et al., 2013; Lee et al., 2004; Oke et al., 1991). Anyhow, the rainfall and/shower were still played role in decreasing outside room temperature while inside room temperature not only higher temperature but also gradually lowering due to low heat translocations through lightweight-concrete along with low thermal conductivity in taking longer lag time (Arneth \& Stichlmair, 2001; Sellers, 1965; Hartman, 1994; Heilman \& Brittin, 1989; Ashktorab et al., 1989; Chunkao, 1979; Gates, 1965; 1980).

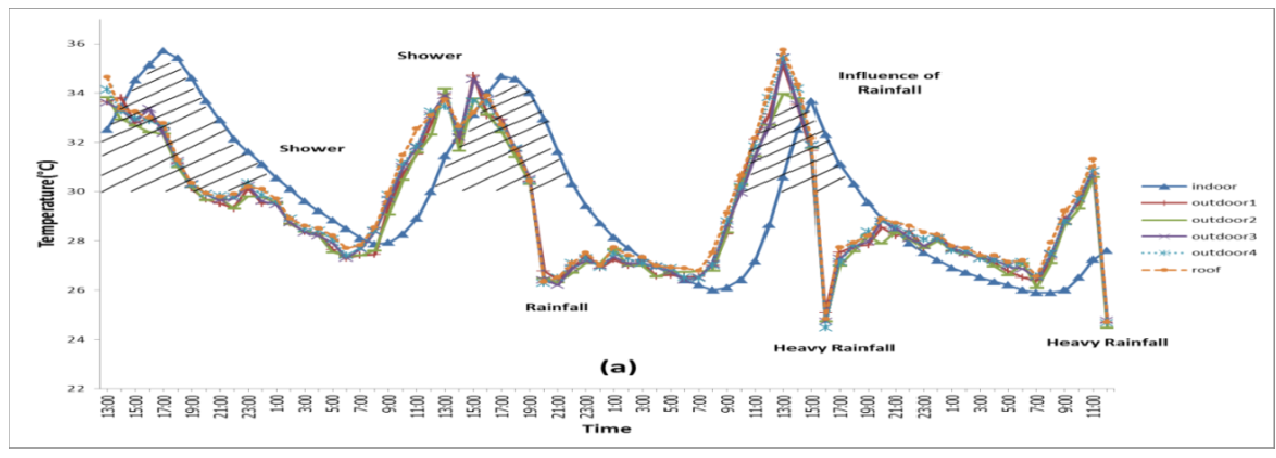



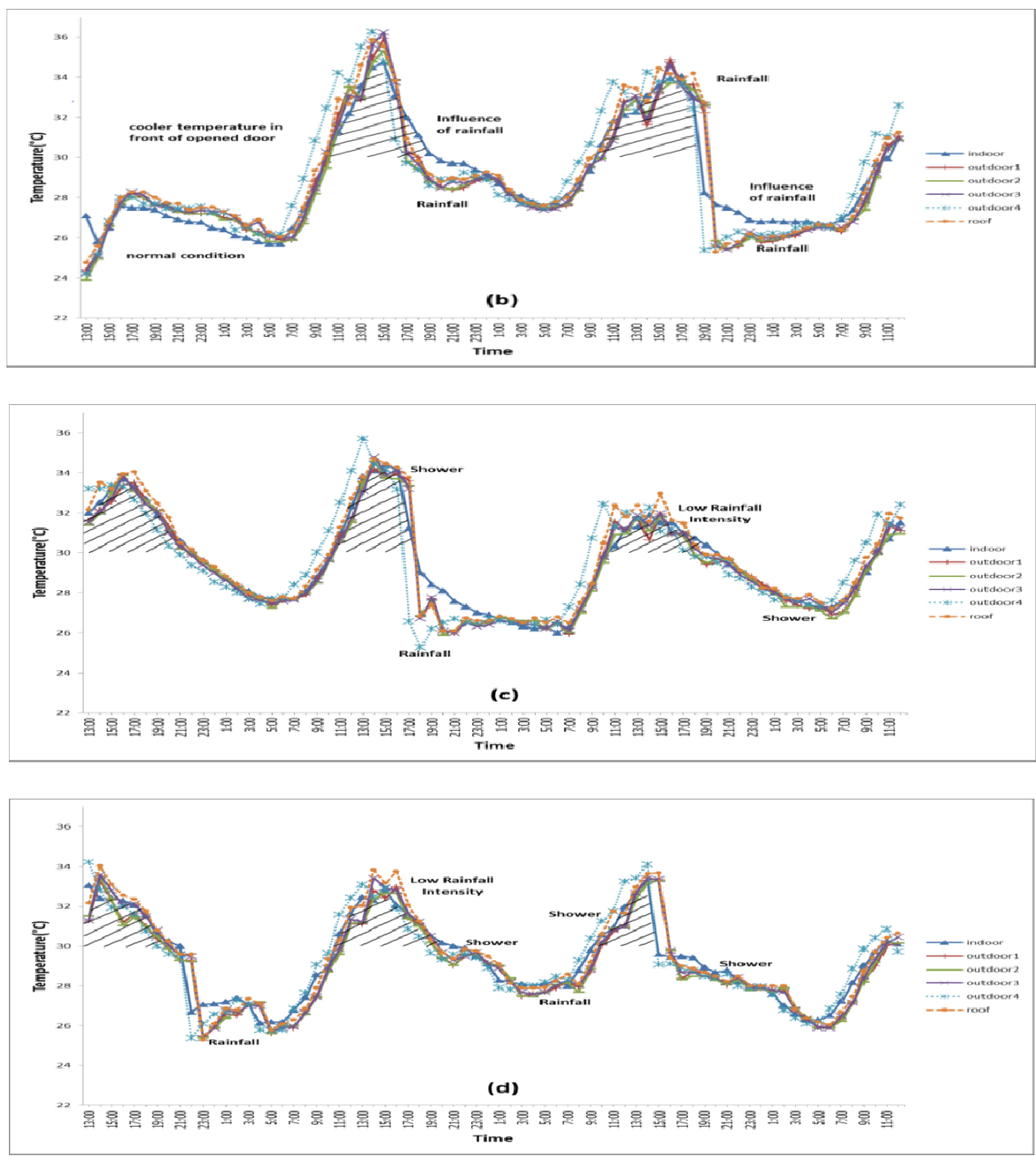

Figure 4. Daily temperature of flattop-concrete roof, outside and inside lightweight-concrete-wall room ( $2.5 \mathrm{~W} \mathrm{x}$ $2.5 \mathrm{~L} \times 2.5 \mathrm{H} \mathrm{m}$ ) after three-day-consecutive measurement in order to insist how to live with comfortably everyday lifestyle (a) Closed Door and Closed Window (b) Opened Door and Closed Window (c) Closed Door and Opened Window (d) Opened Door and Opened Window

Accordingly, lessons learnt from 4-case experiments could be expressed that the inside room temperature was exactly lower than outside room along with lag-time difference of 2.0, 1.5, 1.5, and 1 hours because of low and high thermal conductivity lightweight-concrete walls and flattop-concrete roof of experimental room, especially. The above results indicated that flattop-concrete roof plaid important role in translocating heat energy from outside to inside and from inside to outside room by heat conduction and storage processes. In other words, the uncomfortable conditions for living in the small room $(2.5 \mathrm{~L} \mathrm{X} 2.5 \mathrm{~W}$ X $2.5 \mathrm{H} \mathrm{m})$ were presumably at 2 hours for closing door and window, 1.5 hours for either opening door or window, and 1 hour for open both door and window. Anyhow, the reradiating heat energy from ceiling of flattop-concrete house was supposed to be the main factor involving with less changing room temperature due to high heat conductivity. Since the decrease of sensible heat flux on flattop-concrete roof and surroundings was absorbed to change into latent heat flux by green plants through the evapotranspiration processes before heat energy translocation to the ceiling of the room as pointed out by Gates (1965; 1980), Geiger \& Todhunter (2003), Abou-Korin (2014), Ashktorab et al (1989), Botkin \& Keller (2011), Bowen (1926), Chun \& Guldmann (2014), Chunkao (1971; 1979; 2004), Coseo \& Larsen (2014), Maimaitiyiming et al (2014), Mangone \& van der Linden (2014), Heilman \& Brittin (1989), Holland et al (2013), Honjo \& Takakura (1990-1991), Lee et al (2004), Verma et al (1978), Wolf et al (2008). 


\subsection{Useable Pudsaon for Sensible Heat Absorption}

Pudsaon or Cape Jasmine (Gardenis jasminoides J.Ellis) was selected to use for sensible heat absorption by evapotranspiration process before conducting through mainly empty-flattop-concrete roof into room and some from four-lightweight-concrete walls as received from re-radiation of College of Environment and Kasetsart University car-park buildings which placed on heating asphalt-open space as shown in Figure 2. Naturally, Pudsaon is a light-demander bush with height of 1-2 meters, putting out more twigs and branches, one by one in cone-formed stems, single-thick leaf with absorbing water, pear-leaf tip, light-green color leaf, white-color and thick-petal flower, all-year flowering with strong smell, flower size between 7-8 meters in diameter, and high capacity of water-osmotic-absorbed root. It can be well grown in coconut flake with soaking water which is presumably identified as phreatophyte with deep-rooted plant obtaining its water from the water table in collaborating with high transpiration rate and nearly non-stopped processing.

Experimentally, the 6-stem usage pattern of 4-month-age Cape Jasmine bush plants with averaged-projected crown areas of $2,225 \mathrm{~cm}^{2}$ were grown in $616 \mathrm{~cm}^{2}$ surface-area pots containing high water-holding-capacity coconut flake which is holding the bulk density of $0.83 \mathrm{~g} / \mathrm{cc}$ and total porosity $76 \%$ by volume. In addition, the water holding capacity of coconut flake was more than its oven-dry weight about 5 times that could be available for continuous evapotranspiration from both non-planting and planting Pudsaon or Cape Jasmine plants. The results found evaporated water of Cape Jasmine plant ranging 10 to $170 \mathrm{~g} / \mathrm{pot}$ for 3-hr measurement and converting in latent heat flux ranging between 0.01 to $0.21 \mathrm{cal} / \mathrm{cm}^{2} / \mathrm{min}$ while control plots (no-planting) was ranged between 50 to $352 \mathrm{cc} /$ pot for 3-hr measurement and converting in latent heat flux between 0.07 to 0.51 $\mathrm{cal} / \mathrm{cm}^{2} / \mathrm{min}$ as shown in Table 2 and Figure 5.

Table 2. Latent heat flux through evapotranspiration process for absorbing heat around for pre-test by 5-experimental plots without and with planting as placed on asphalt road and surrounding College of Environment Building, Kasetsart University car prak building, and sewer canal in western direction

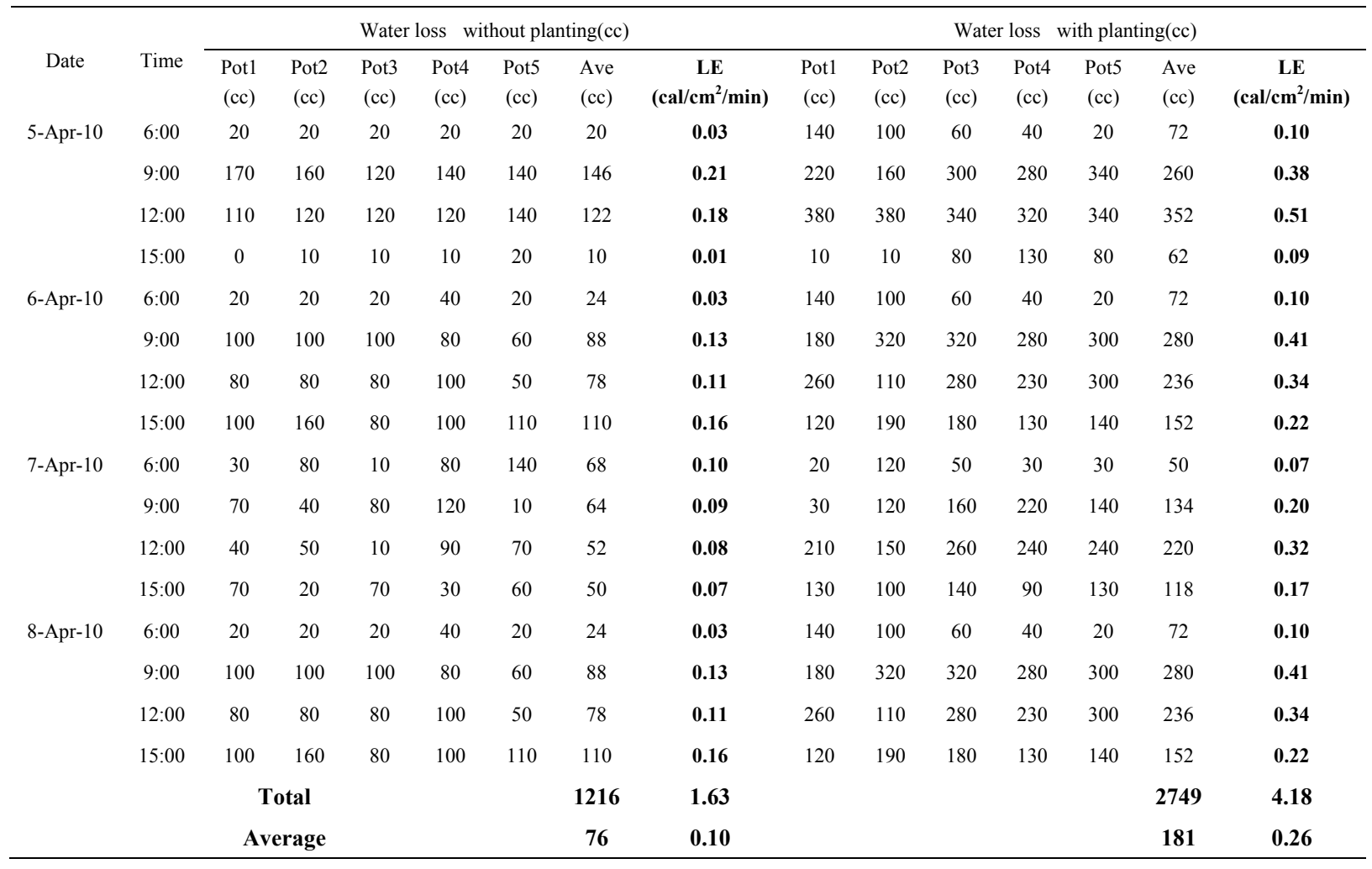




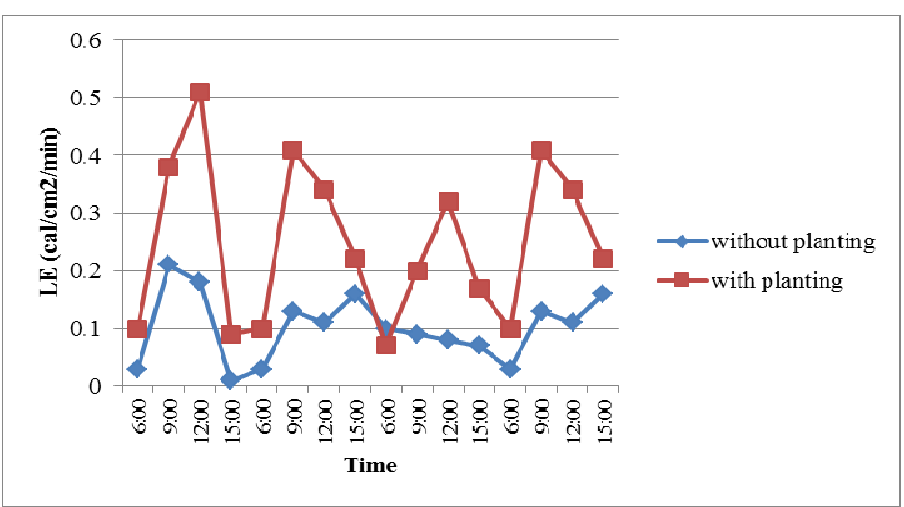

Figure 5. Daily latent heat flux of pretest through the evapotranspiration process from 5-experimental pots without and with planting as contained the organic soils for with and without growing plants in deducting heat outside experimental room

In experimental point of view, an amount of water usage in planting pots higher than control pots due to plant roots having potentials to draw capillary water which were coated around soil particles and plant roots that becoming transpiration plus evaporation from control pots (opening surface) and panting Cape Jasmine pots. In consequence, the control pots were found less water usage owning to more macropores of coconut flake that could be slow down the continuity of evaporating water supply, and they also dried out due to heating from direct solar radiation. In addition, the averaged water-loss ratio between without planting and with planting Pudsaon or Cape Jasmine was found about $1: 2.3$ (See Table 2) due to phreatophytic Cape Jasmine or Pudsaon in collaborating with coconut flake in growing pots containing coconut flake

As stated before, this section of research was needed to focus on feasibility study of water usage for evapotranspiration from experimental pots containing coconut flake with and without planting Pudsaon or Cape Jasmine (Gardenia jasminoides J.Ellis) in order to determine heat absorption from incoming solar radiation and including outgoing re-radiation from KU College of Environment building, water body in canal and asphalt road as described by Odum \& Barrett (2004), Akbari et al (1992), Honjo \& Takakura (1990-1991), Ferreira \& Condessa (2012), Mangone and Van der Linden (2014), Ng et al (2012), Oke et al (1991), Santamouris (2014), Zhang et al (2013) and McPherson (1993). It was expected that the experimental pots containing coconut flake with and without planting Pudsaon used water through evapotranspiration process could make room temperature decreasing (Juwarkar et al., 1995; Hammer, 1989; Ahn \& Mitsch, 2002; Jenssen et al., 1994; Keddy, 2010; Bowen, 1926; Lai et al., 2011; Dicken et al., 2013; Gates, 1980; Hartman, 1994; Holland et al., 2013; Coseo \& Larsen, 2014).

Besides, this research results would be convinced to pinpoint the feasibility of pot-planting employing to deduct the conducted heat as directly received from the sun in which the lightweight-concrete room with flattop-concrete roof. The high water holding capacity coconut flake paid very much significant role in evapotranspiration process from planting Pudsaon or Cape Jasmine pots as main heat absorption rather than control pots. In other words, greenery cover of planting Cape Jasmine pots for heat absorption through evapotranspiration process is exactly feasible in theory and practices for making the decreasing temperature inside flattop-concrete roof and lightweight concrete-wall room (Buckman \& Brady, 1969; Baver, 1966; Baver et al., 1972; Lai et al., 2011; Sellers, 1965; Gates, 1965; 1980; Geiger et al., 2003; Hartman, 1994; Holman, 2009; Holland et al., 2013; Honjo \& Takakura, 1990-1991; Lee et al., 2004; Odum \& Barrett, 2004; Garratt, 1978; Deacon, 1949; Dicken et al., 2013; Chunkao, 1971; 1979; Akbari et al., 1992; Ashktorab et al., 1989; Bowen, 1926; Chun \& Guldmann, 2014; Maimaitiyiming et al., 2014; Mangone \& Van der Linden, 2014; Mcpherson \& Rowntree, 1993; Santamouris, 2014; Verma et al., 1978; Shahiden et al., 2012).

\subsection{Heat Conduction through Lightweight-Concrete-Room Walls}

The average temperature inside and outside flattop-concrete house with lightweight-concrete walls in case of no-planting Pudsaon found inside temperature at daytime $30.01{ }^{\circ} \mathrm{C}$ and $29.26{ }^{\circ} \mathrm{C}$ at nighttime (average $29.69{ }^{\circ} \mathrm{C}$ ), outside temperature at daytime $30.30{ }^{\circ} \mathrm{C}$ and at nighttime $27.05{ }^{\circ} \mathrm{C}$ (average $28.68{ }^{\circ} \mathrm{C}$ ) and roof temperature at daytime $30.64{ }^{\circ} \mathrm{C}$ and nighttime $27.05{ }^{\circ} \mathrm{C}$ (average $28.68{ }^{\circ} \mathrm{C}$ ), and roof temperature at daytime $30.64{ }^{\circ} \mathrm{C}$ and at nighttime $27.11{ }^{\circ} \mathrm{C}$ (average $28.90{ }^{\circ} \mathrm{C}$ ) as shown in Table 3. The influence of no-planting Pudsaon on 
flattop-concrete roof was evidently seen by higher inside temperature at daytime very close to nighttime due to CDCW condition making extreme slowly ventilation, and intensively re-radiation from concrete ceiling of the room at daytime and lightly at nighttime. The outside and roof temperature were shown in greater decreases than inside temperature which was not almost lowered down according to low heat conductivity of lightweight-concrete walls except extremely cool weather by rainwater.

In case of planting Pudsaon (Cape Jasmine) and placing on flattop-concrete roof, the inside temperature at daytime $29.89{ }^{\circ} \mathrm{C}$ and nighttime $30.62{ }^{\circ} \mathrm{C}$ (average $30.49{ }^{\circ} \mathrm{C}$ ) for $\mathrm{CDCW}$ conditions were more or less the same owning to slowly heat transferring through lightweight-concrete walls and ceiling concrete re-radiation. While outside temperature was almost shown in opposite result from daytime $31.55{ }^{\circ} \mathrm{C}$ to nighttime $28.51{ }^{\circ} \mathrm{C}$ which happened the same trend in roof temperature by indicating daytime temperature $31.39{ }^{\circ} \mathrm{C}$ and nighttime $28,53{ }^{\circ} \mathrm{C}$ (see Table 3). However, the measured temperature were pointed out at $30.34{ }^{\circ} \mathrm{C}$ at daytime and $29.20{ }^{\circ} \mathrm{C}$ at nighttime with very narrow difference which influenced by open door for convenient ventilation to enhance heat exchange likewise happening with outside and roof temperature. Anyhow, the decreases of outside temperature (in case of ODCW condition) from daytime $30.93{ }^{\circ} \mathrm{C}$ and nighttime $28.14{ }^{\circ} \mathrm{C}$ (average $29.54{ }^{\circ} \mathrm{C}$ ) as well as roof temperature at daytime $31.55^{\circ} \mathrm{C}$ and nighttime $28.16^{\circ} \mathrm{C}$ (average $29.86{ }^{\circ} \mathrm{C}$ ) were narrow because of re-radiating objects (buildings, asphalt road, and water body) to elevating degrees of their temperature. In CDOW condition, the difference of inside temperature was wider than CDCW and ODCW conditions by having temperature at daytime $30.00{ }^{\circ} \mathrm{C}$ and at nighttime $28.93{ }^{\circ} \mathrm{C}$ (average $29.22{ }^{\circ} \mathrm{C}$ ) while outside temperature was also somewhat wider temperature between daytime $30.09{ }^{\circ} \mathrm{C}$ and nighttime $27.55{ }^{\circ} \mathrm{C}$ (average $28.82{ }^{\circ} \mathrm{C}$ ). It also happened in roof temperature at daytime $30.14^{\circ} \mathrm{C}$ and nighttime $27.60{ }^{\circ} \mathrm{C}$ (average $28.87^{\circ} \mathrm{C}$ ) which still indicated in the same trend of decreasing temperature differences with ODCW room activities. Moreover, the condition of ODOW room activities was followed the expectation of wider different temperature by designating at daytime $31.41{ }^{\circ} \mathrm{C}$ and nighttime $28.46{ }^{\circ} \mathrm{C}$ (average $29.94{ }^{\circ} \mathrm{C}$ ) for inside temperature, at daytime $32.00{ }^{\circ} \mathrm{C}$ and nighttime $29.34{ }^{\circ} \mathrm{C}$ (average $30.67{ }^{\circ} \mathrm{C}$ ) for outside temperature, at daytime $31.18{ }^{\circ} \mathrm{C}$ and $27.81{ }^{\circ} \mathrm{C}$ (average $28.50{ }^{\circ} \mathrm{C}$ ) as illustrated in Table 3.

Table 3. Inside and outside temperature of lightweight-concrete-wall room as obtained from 4 conditions of each 3 -consecutive-day measurements under planting-plot greenery covering over concrete roof

\begin{tabular}{|c|c|c|c|c|c|c|c|c|c|c|}
\hline \multirow[t]{3}{*}{ Treatment } & \multirow{3}{*}{$\begin{array}{l}\text { Room } \\
\text { Activity }\end{array}$} & \multicolumn{9}{|c|}{ Averaged Temperature, ${ }^{\circ} \mathrm{C}$} \\
\hline & & \multicolumn{3}{|c|}{ Inside } & \multicolumn{3}{|c|}{ Outside } & \multicolumn{3}{|c|}{ Roof } \\
\hline & & Day & Night & Avg. & Day & Night & Avg. & Day & Night & Avg. \\
\hline No-Planting & $\mathrm{CDCW}$ & 30.1 & 29.26 & 29.64 & 30.30 & 27.05 & 28.68 & 30.64 & 27.11 & 28.90 \\
\hline \multirow[t]{4}{*}{ Planting } & CDCW & 29.89 & 30.62 & 30.49 & 31.55 & 28.51 & 30.03 & 31.39 & 28.53 & 29.96 \\
\hline & ODCW & 30.34 & 29.20 & 28.27 & 30.93 & 281.4 & 29.59 & 31.55 & 28.16 & 29.86 \\
\hline & CDOW & 30.00 & 28.43 & 29.22 & 30.09 & 27.55 & 28.82 & 30.14 & 27.60 & 28.87 \\
\hline & ODOW & 31.41 & 28.46 & 29.94 & 32.00 & 29.34 & 30.67 & 31.18 & 27.81 & 29.50 \\
\hline
\end{tabular}

Remarks: $\quad \mathrm{CDCW}=$ Closed Door and Closed Window $\quad$ ODCW $=$ Open Door and Closed Window

$$
\mathrm{CDOW}=\text { Closed Door and Open Window } \quad \text { ODOW }=\text { Open Door and Open Window }
$$

The previous explained research results were brought to stress that closed both the door and the window caused to ventilate between inside room heat energy and outside re-radiation from surrounded buildings, asphalt road, and water body in westerly KU drainage canal. Completion of closing door and window was initiated to make room warm because of no heat exchange between inside and outside, and also daytime heat transferring from flattop-concrete roof was stored rather high speed but slow outgoing re-radiation to outside from concrete roof and through low heat conductivity of lightweight-concrete walls. Opening either door or window provided releasing inside room heat energy outgoing easily to the outer space but the research findings found longer lag time because of higher outside temperature as received from re-radiating objects. In case of opening door and window at the same time, the lag time seemed narrow in temperature differences between daytime and nighttime, cool weather and rainwater causing the wider different temperature which indicated low room temperature and more comfortable everyday lifestyle. When planting Pudsaon (Cape Jasmine) on the flattop-concrete roof together with lightweight-concrete walls could be provided well ventilation and heat exchange which cause wider temperature differences (shorter lag time). The above statements were obtained from research results of Gates (1965,1980), Geiger et al (2003), Abou-Korin (2014), Ashktorab et al (1989), Botkin \& Keller (2011), Bowen (1926), Chun \& Guldmann (2014), Chunkao (1971), Coseo \& Larsen (2014), Maimaitiyiming et al 
(2014), Mangone \& Van der Linden (2014), Heilman \& Brittin (1989), Holland et al (2013), Honjo \& Takakura (1990-1991), Lee et al (2004), Verma et al (1978), Wolf et al (2008), Garratt (1978), Deacon (1949), Dicken et al (2013), Chunkao (1971; 1979), Akbari et al (1992), Mcpherson \& Rowntree (1993), Santamouris (2014), and Shahiden et al (2012).
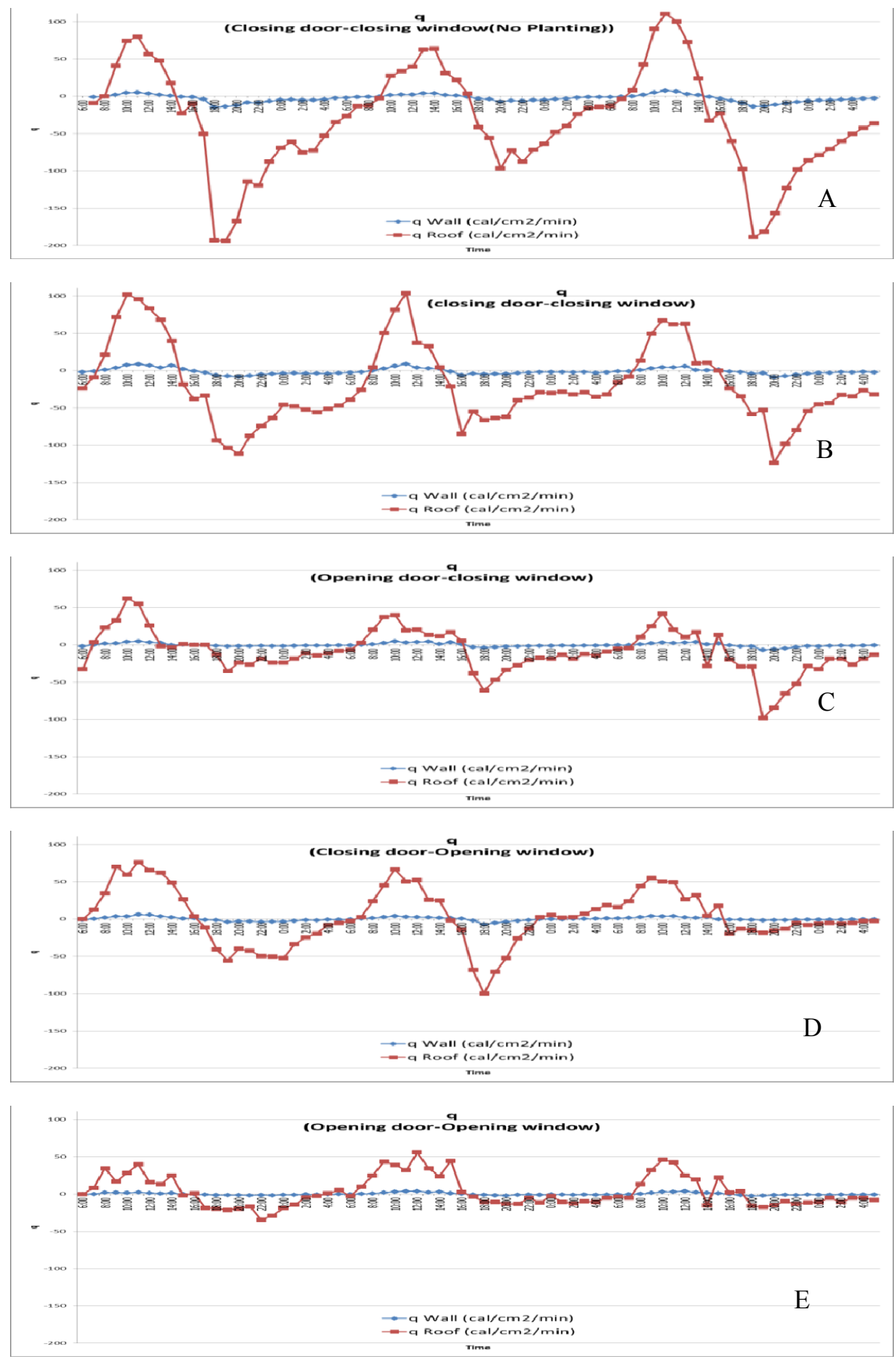

Figure 6. Conducting Heat in and out of room as assembled by lightweight-concrete walls and flattop-concrete roof under the conditions of (a) closing door and closing window (CDCW-no planting), (b) closing door and closing window (CDCW-planting), (c) open door and closing window (ODCW-planting), (d) closing door and opening window (CDOW-planting), (e) opening door and opening window (ODOW-planting)

It is obvious that the low heat conductivity of four-side walls of lightweight-concrete walls was performed in 
steadily heat transferring with small fluctuation, no matter the flattop-concrete roof that being planted or opened as illustrated in Figure 6. Nevertheless, the in-transferring of heat into and out-transferring from lightweight-concrete walls were somewhat influenced by high rate of heat conduction, particularly without planting (see Figure 6a) but not being evident almost on concrete-roof-top planting (see Figures 6b,6c,6d,6e). In opposite way, the occurrences of in and out transferring through concrete roof were shown in evidences of their fluctuation on both of planting and no planting. As hypothesized the results, heat storage inside experimental room was kept longer time when either door or window opened (see Figure 6e) than both of them in closing states (see Figures 6a, 6b) but opening window paid vital role in low and short-time heat keeping than only opening door (see Figures 6c, 6d).

An ambient air temperature was paid significant role in heat conduction from lightweight-concrete room, particularly in-case closing door and closing window without and with planting on the concrete roof (Figures 6a, 6b) due to high potentials of heat storage inside to force it transferring. In contrary, while either opening door or opening window as well as opening on both of them were found somewhat low rates of heat transfer by conduction through the lightweight-concrete walls as shown in Figures 6c, 6d, 6e) owning to heat being able to transfer through opened door and window without any interruption rather than piecing through lightweight-concrete-wall heat conductivity. Evidently, the outgoing radiation performance ware almost unbelievably happened while both the door and window were opened during the experimental periods, but there were very small part of inflow-heat-conduction into experimental (Figure 6e) besides, it was obvious that growing plants around the houses would be the heat absorption to decrease inside house temperature down to comfortable temperature for human everyday life one way or another.

\subsection{Planting Pudsaon for Sensible Heat Absorption}

After planting Pudsaon (Cape Jasmine) on flattop-concrete house with lightweight-concrete walls, evaporated water was conducted for 4-day consecutive measurement and found at daytime $625 \mathrm{~g} / \mathrm{d} / \mathrm{p}$ and nighttime $93 \mathrm{~g} / \mathrm{d} / \mathrm{p}$ (total $718 \mathrm{~g} / \mathrm{d} / \mathrm{p}$ ) for CDCW, at daytime $718 \mathrm{~g} / \mathrm{d} / \mathrm{p}$ and nighttime $101 \mathrm{~g} / \mathrm{d} / \mathrm{p}$ (total $819 \mathrm{~g} / \mathrm{d} / \mathrm{p}$ ) for ODCW, at daytime $547 \mathrm{~g} / \mathrm{d} / \mathrm{p}$ and nighttime $92 \mathrm{~g} / \mathrm{d} / \mathrm{p}$ (total $639 \mathrm{~g} / \mathrm{d} / \mathrm{p}$ ) for CDOW, at daytime $660 \mathrm{~g} / \mathrm{d} / \mathrm{p}$ and nighttime 129 $\mathrm{g} / \mathrm{d} / \mathrm{p}$ (total $789 \mathrm{~g} / \mathrm{d} / \mathrm{p}$ ) as shown in Table 4 . It was indicated that the second day of experiment found the highest amount of evaporated water (total $819 \mathrm{~g} / \mathrm{d} / \mathrm{p}$ ), the first day $(718 \mathrm{~g} / \mathrm{d} / \mathrm{p}$ ) and the fourth day (total $789 \mathrm{~g} / \mathrm{d} / \mathrm{p}$ ) as medium amount, and the third day as the lowest amount (total $639 \mathrm{~g} / \mathrm{d} / \mathrm{p}$ ) which depended upon directly to the degrees of outside and roof temperature (see Tables 3 and 4). If the ratio between daytime and nighttime evaporated water is considered, the results found 7:1 for first day, 7:1 for second day, 6:1 for third day, and 5:1 for forth day which ranged between 5:1 and 7:1 depending on temperature fluctuation (see Tables 3 and 4) as followed the research results of Chunkao (1971), Akbari et al (1992), Bowen (1926), Coseo \& Larsen (2014), Deacon (1949), Heilman \& Brittin (1989), Lee et al (2004), Maimaitiyiming et al (2014), Mangone \& Van der Linden (2014), Mcpherson (1988), Ng et al (2012), Savage et al (2009), Zhang et al (2013), and Wolf et al (2008).

Table 4. Latent heat (LE) as converted from evaporated water through evapotranspiration for absorbing sensible heat from direct solar radiation and outgoing re-radiation of surrounded buildings, asphalt road, and water body nearby single-room and flattop-concrete house with lightweight-concrete room

\begin{tabular}{|c|c|c|c|c|c|c|c|c|}
\hline \multirow[t]{2}{*}{ Date } & \multirow{2}{*}{$\begin{array}{l}\text { Room } \\
\text { Activity }\end{array}$} & \multicolumn{3}{|c|}{ Evaporated water $(\mathrm{g} / \mathrm{d} / \mathrm{p})$} & \multicolumn{3}{|c|}{$\mathrm{LE}\left(\mathrm{cal} / \mathrm{cm}^{2} / \mathrm{min}\right)$} & \multirow[t]{2}{*}{ Remarks } \\
\hline & & Day & Night & Total & Day & Night & Average & \\
\hline $9-11 / 9 / 14$ & CDCW & 625 & 93 & 718 & 0.23 & 0.03 & 0.13 & Latent heat of \\
\hline $12-14 / 9 / 14$ & ODCW & 718 & 101 & 819 & 0.26 & 0.04 & 0.15 & vaporization is \\
\hline $15-17 / 9 / 14$ & CDOW & 547 & 92 & 639 & 0.20 & 0.03 & 0.12 & equivalent to 583 \\
\hline \multirow[t]{2}{*}{$18-20 / 9 / 14$} & ODOW & 660 & 129 & 789 & 0.24 & 0.05 & 0.15 & $\mathrm{cal} / \mathrm{g}$ \\
\hline & Average & 638 & 104 & 742 & & & 0.14 & \\
\hline \multirow[t]{2}{*}{ Remarks: } & $\mathrm{CDCW}=\mathrm{C}$ & 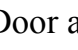 & 8 & WW & $\mathrm{OD}$ & $m a$ & $\mathrm{~d}$ & Window \\
\hline & $\mathrm{CDOW}=\mathrm{Cl}$ & Door a & Open W & & ODO & Open & and $C$ & n Window \\
\hline
\end{tabular}

Accordance with research objectives concerning with absorbing sensible heat to latent heat through evapotranspiration process, the results found LE at daytime $0.23 \mathrm{cal} / \mathrm{cm}^{2} / \mathrm{min}$ and at nighttime $0.03 \mathrm{cal} / \mathrm{cm}^{2} / \mathrm{min}$ (average $0.13 \mathrm{cal} / \mathrm{cm}^{2} / \mathrm{min}$ ) for CDCW, at daytime $0.26 \mathrm{cal} / \mathrm{cm}^{2} / \mathrm{min}$ and nighttime $0.04 \mathrm{cal} / \mathrm{cm}^{2} / \mathrm{min}$ (average $0.15 \mathrm{cal} / \mathrm{cm}^{2} / \mathrm{min}$ ) for ODCW, at daytime $0.20 \mathrm{cal} / \mathrm{cm}^{2} / \mathrm{min}$ and nighttime $0.03 \mathrm{cal} / \mathrm{cm}^{2} / \mathrm{min}$ (average 0.12 
$\mathrm{cal} / \mathrm{cm}^{2} / \mathrm{min}$ ) for CDOW, and at daytime $0.24 \mathrm{cal} / \mathrm{cm}^{2} / \mathrm{min}$ and nighttime $0.05 \mathrm{cal} / \mathrm{cm}^{2} / \mathrm{min}$ (average 0.15 $\mathrm{cal} / \mathrm{cm}^{2} / \mathrm{min}$ ) as shown in Table 4 . The results as presented in Table 4 were informed that the sensible heat was converted to latent heat ranging $0.12-0.15 \mathrm{cal} / \mathrm{cm}^{2} / \mathrm{min}$ equivalent to decreasing outside temperature

$1.00{ }^{\circ} \mathrm{C}-1.11{ }^{\circ} \mathrm{C}$

The previous pretesting experimental results were brought up to express that the greenery-plant pots played significant roles in absorbing sensible heat of surroundings through the processes of evaporation and transpiration which caused to lower temperature as explained by Mangone \& Van der Linder (2014), Ng et al (2012), Oke et al (1991), Santamouris (2014), Verma et al (1978), and Zhang et al (2013), but it was still needed more information to respond the objectives, that is, understanding for consecutive measurement.

To achieve those principles, the 36-pot plants as the greenery cover on flattop-concrete roof were placed down as designated their position, and everyday watering (approximately equivalent to the amount of evaporating water) at 06:00, 12:00, and 18:00 for three-consecutive days together with all-time cording temperature at above the flattop-concrete roof, 1-m far from 4-side rooms as made of lightweight-concrete walls which settled outside and inside room (see Table 2). For pointing the influences of converting evapotranspiration water to become the latent heat flux (LE) on cooling roof concrete and room temperature, the comparison of experimental study was taken between with and without pot-planting on the roof. The results can be expressed in the following 5 cases:

\section{Case 1: CDCW Without Planting on Flattop-Roof}

The inside temperature from 3-day consecutive experiments was evidently shown higher than outside temperature when the door and window of the room were completely closed as well as the other 4 cases with planting-pot on roof as illustrated in Table 3 and Figure 7. The lag time of inside daytime maximum temperature was about 4-8 hours (averaging 6 hours) and nighttime minimum temperature 2-5 hours (averaging 3.5 hours), and also the lag-time difference about 2.5 hours as shown in Figure 7 a. It could be directed that the inside temperature was surely higher than outside temperature in case of closed door and closed window of room without planting-pot on the flattop-concrete roof which made lag

\section{Case2: CDCW Planting Plots on Flattop-Concrete Roof}

When the greenery covering of 36 planting pots on the concrete roof, the inside temperature was drastically lowered than outside maximum temperature approximately $1.0^{\circ} \mathrm{C}$ to $2.0^{\circ} \mathrm{C}$, and higher than outside temperature about $1.0^{\circ} \mathrm{C}$ to $1.5{ }^{\circ} \mathrm{C}$. Even if the 4 -side air temperature around the room were rapidly changed, the inside temperature was still unchanged on both the maximum and minimum temperature (see Figure 6b). Intensive consideration found the lag time of daytime maximum temperature 3-6 hours (averaging 4.5 hours), nighttime minimum temperature 2-4 hours (averaging 3.0 hours), and making the lag time difference of 1.5 hours.

\section{Case3: ODCW Planting Pots on Flattop-Concrete Roof}

When the opened door and closed window was activated together with 36 planting pots on the concrete roof, the inside maximum temperature was still lower than the outside temperature almost the same as Case 2 but a little lowering differences between inside minimum and outside minimum temperature as illustrated in Figure6c. Such results made the lag time of 3-5 hours (averaging 4 hours) for daytime maximum temperature, 2-4 hours for nighttime minimum temperature, and making the lag-time difference of 1 hour.

\section{Case4: CDOW Planting Pots on Flattop-Concrete Roof}

Surprisingly, although the inside maximum temperature was lower than outside maximum temperature $0.5{ }^{\circ} \mathrm{C}$ to $1.0{ }^{\circ} \mathrm{C}$ the inside minimum temperature still higher than outside minimum temperature quite higher ranged between $1.5^{\circ} \mathrm{C}$ to $2.0{ }^{\circ} \mathrm{C}$ (see Figure $6 \mathrm{~d}$ ). It was noticed that the depletion curves were sharply decreased from the maximum down to the minimum. It was clearly evident that planting Pudsaon in growing pots containing coconut flake influenced to have higher absorbing heat. The said results were indicated the lag time 3-4 hours (averaging 3.5 hours) for daytime maximum temperature, of 2-3 hours for nighttime minimum temperature, and making the lag-time difference of 1 hour. 

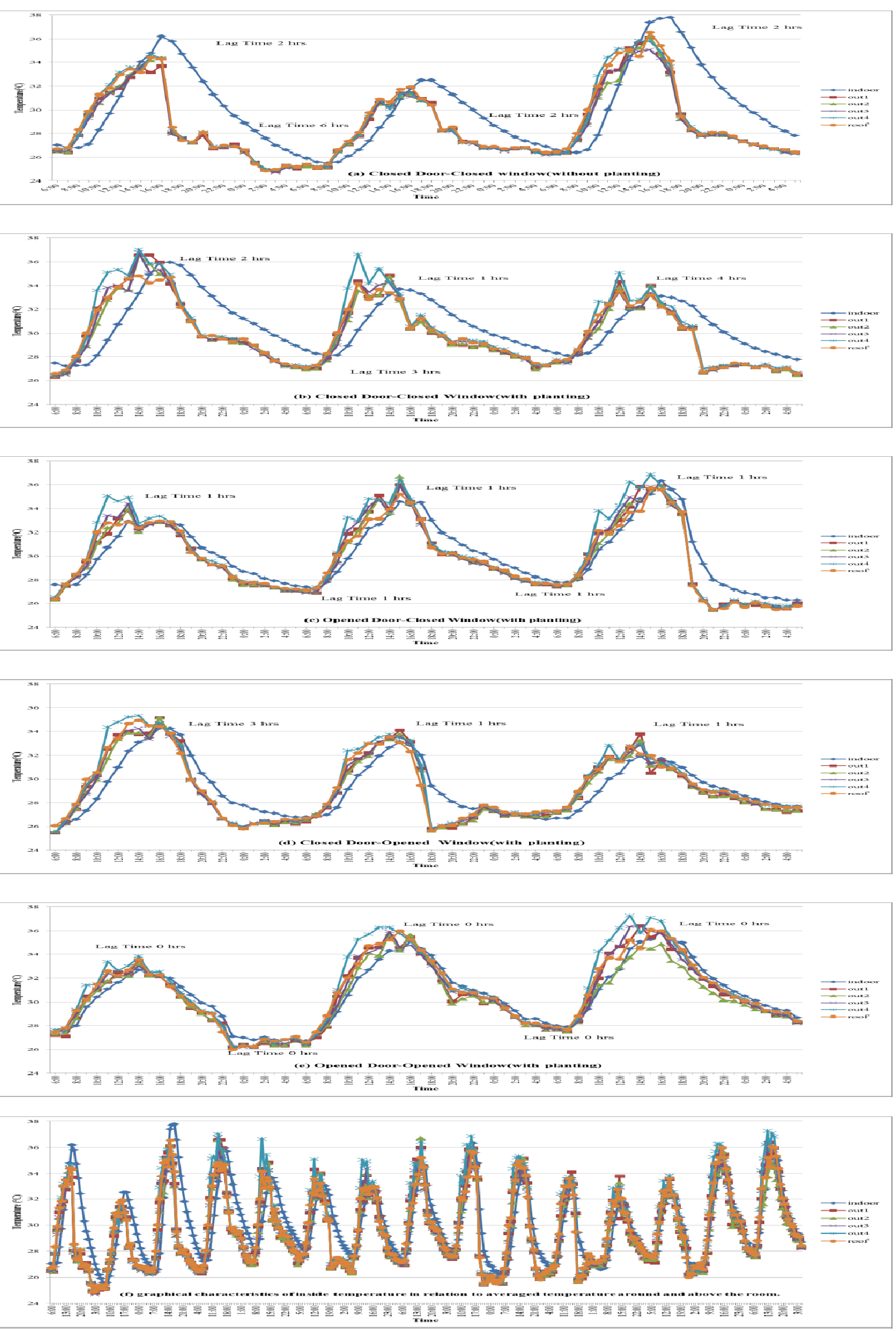

Figure 7. Air temperature as measured inside and outside lightweight-concrete walls without and with planting plots on concrete roof for (a) closed door and closed window without planting-pot concrete, (b) closed door and 
closed window with planting-pot concrete, (c) opened door and closed window with planting-pot concrete, (d) closed door and open window with planting-pot concrete, (e) opened door and opened window with planting-pot concrete by 3-day consecutive measuring, and (f) inside temperature in relation to averaged temperature around the room and upper roof

\section{Case5: ODOW Planting on Flattop-Concrete Roof}

The case of opened door and opened window was influenced on ventilation inside room that made the temperature graphic forms very similar as illustrated in Figure6e, the maximum inside temperature being lower than the surrounding-area temperature as well as roof temperature. Besides, the minimum inside and outside temperature was more or less the same forms and trends of temperature. In other words, both opened door and opened window were able to stir air temperature running around the room that made inside temperature nearly homogeneous with lowering for longer stay rather than either closed door or closed window. However, the graphical characteristics of inside temperature were shown off evidences in part of recession curves in case of closed both door and window, either closed door or closed window but they were almost overlapped each other when both the door and the window were opened for wind blowing through the room as seen in Figure6. The lag time of daytime maximum temperature was 1-2 hours (averaging 1.5 hours), nighttime minimum temperature 0-2 hours (averaging 1 hour), and making the lag-time difference of 0.5 hour.

The total picture as explained above, the greenery-planting pots were plaid vital role in deducting temperature inside experimental room as assembling of flattop-concrete roof and lightweight-concrete walls, especially when the door and widow were opened (at the same time) rather than either only opening door or only opening window, but it was no satisfied whenever both closing door and window at the same time. The most important issue should be pointed out that greenery cover by growing Pudsaon (Cape Jasmine plant) phreatophyte on flattop-concrete roof can deduct the lag time between maximum and minimum room temperature ranging from 1-2 hours (without planting) to $0.5-1.5$ hours (with planting). Evidently, the greenery cover on flattop-concrete-roof room with lightweight-concrete walls was capable to decrease the maximum room temperature no matter hot or cool weather from $36{ }^{\circ} \mathrm{C}$ down to $30{ }^{\circ} \mathrm{C}$ with the averaging $32{ }^{\circ} \mathrm{C}$. Anyhow, lesson learnt from this experiment would be strongly stressed that greenery cover upper the roof was pronounced as the better heat absorption, even the narrow room being somewhat good enough for living. It is expected that if the bigger size of room together with higher roof as well as more than one windows and/or doors that could be better living than the experimental size of this study.

\section{Conclusion}

The research on growing greenery cover on flattop-concrete roof of single-room house with lightweight-concrete walls for deducting heat conduction as constructed on narrow space was conducted inside Kasetsart University between the College of Environment and car park buildings in dense-populated city of Bangkok during 10 August-30 November 2014. The study was emphasized on feasible living that the people could live in minimum room size of $2.5-\mathrm{m}$ width, 2.5-m length, and $2.5 \mathrm{-m}$ by taking air, room temperature, and heat conduction as indicators. The air and room thermometers were installed about $1 \mathrm{~m}$ in directions of northerly, southerly, easterly, westerly and flattop-concrete roof of single-room (one-door and one-window room) with lightweight-concrete walls, and including above the flattop-concrete roof by alternating closing and opening to the door and widow. The research was implemented into 4 parts: firstly, determining the lag time between maximum and minimum points of air and room temperature; secondly, feasibility study on using Pudsaon or Cape Jasmine growing in pots containing coconut flake for latent heat absorption; thirdly, determining in-translocating heat from outside through lightweight-concrete walls; and finally, study on the influence of planting Pudsaon or Cape Jasmine in pots containing coconut flake for latent heat absorption before transferring through flattop-concrete roof. The results found as follows:-

1) Closed-Open Door and Window Influencing on Room Temperature: CDCW room temperature was found the average at daytime $30.13{ }^{\circ} \mathrm{C}$ and nighttime $29.20{ }^{\circ} \mathrm{C}$ (total average $29.66{ }^{\circ} \mathrm{C}$ ), while ODCW $30.11{ }^{\circ} \mathrm{C}$ at daytime and $28.18{ }^{\circ} \mathrm{C}$ at nighttime (total average $28.78{ }^{\circ} \mathrm{C}$ ), $\mathrm{CDOW} 30.67{ }^{\circ} \mathrm{C}$ at daytime and $28.20{ }^{\circ} \mathrm{C}$ at nighttime (total average $29.43{ }^{\circ} \mathrm{C}$ ), ODOW $30.17{ }^{\circ} \mathrm{C}$ at daytime and $28.09{ }^{\circ} \mathrm{C}$ at nighttime (total average $29.23{ }^{\circ} \mathrm{C}$ ). The highlight was focused on open either door or window and both of them which highlighted on decreasing temperature from CDCW $29.66{ }^{\circ} \mathrm{C}$ to $0.88{ }^{\circ} \mathrm{C}$ for ODCW, $0.23{ }^{\circ} \mathrm{C}$ for $\mathrm{CDOW}$, and $0.43{ }^{\circ} \mathrm{C}$ for ODOW (ranging $0.23{ }^{\circ} \mathrm{C}$ to $0.43{ }^{\circ} \mathrm{C}$ ). It was not surprised on decreasing temperature by either opening door or window and both at daytime due to heat energy around the room and outer space that could be conveniently transferred inside room through opening door or window and both. It is remarkable to point out that the decreasing temperature from $\mathrm{CDCW} 29.20{ }^{\circ} \mathrm{C}$ by 
either opening door or window and both found $1.02{ }^{\circ} \mathrm{C}$ for ODCW, $1.00{ }^{\circ} \mathrm{C}$ for $\mathrm{CDOW}$, and $1.11{ }^{\circ} \mathrm{C}$ for ODOW (ranging $1.00^{\circ} \mathrm{C}$ to $1.11^{\circ} \mathrm{C}$ ).

2) Lag time at daytime: maximum temperature was found 4-7 hours (averaging 5.5 hours) in case of closing both door and window, then decreasing down to 3-6 hours (averaging 4.5 hours) in case of either opening door or window, and 2-5 hours (averaging 3.5 hours) in case of both opening door and window. While lag time at nighttime: temperature was also decreased from 2-5 hours (averaging 3.5 hours) in case of both closing door and window, then decreasing down to 2-4 hours (averaging 3 hours) in case of either opening door or window, and 1-4 hours (averaging 2.5 hours) in case of both opening door and window. Such results made the lag-time difference between maximum and nighttime room temperature was gone down from 2 to 1 hour in which an increase of air ventilation process by opening either door and/or window activities was brought up comfortability on how to spend everyday lifestyle. Remarkably, long duration, high intensity, and often frequency of rainfall were identified as very important factors for changing in decreasing lag time while the opposite values enhanced an increase of lag time. Closing both door and window or either one could not be conditioned for everyday lifestyle in dense and populated Bangkok city.

3) Using Pudsaon plant (bush) or Cape Jasmine (Gardenis jasminoides J.Ellis) as grown in growing pot containing coconut flake was feasible because it is classified as phreatophyte with deeper root to absorb deeper soil water through evapotranspiration process, plus high water holding capacity of coconut flake as water supplier which can absorb surrounding sensible heat to latent heat. Anyhow, the influence of planting Pudsaon was evident on decreasing lag time 3-6 hours (averaging 4.5 hours) for both closing door and window, 3-5 hours (averaging 4 hours) for opening door and closing window, 3-4 hours (averaging 3.5 hours) for opening window and closing door, and 1-2 hours (averaging 1.5 hours) for both opening door and window. The differences of lag time were 1.5 hours for both closing door and window, then decreasing down to 1 hour for both opening door or window, and 0.5 hour for both opening the door and window. The main factor was depended on heat absorption through the process of Pudsaon/ Cape Jasmine evapotranspiration in term of latent heat absorption as well as rainfall period and activities of opening door or/and window for enhancing cooler air ventilation.

4) Lightweight-concrete walls of single-room house with flattop-concrete roof were eligible to protect heat transferring from hot air outside into room rather than from room to outside, except opening both door and window at the same time.

5) Greenery cover by placing Pudsaon or Cape Jasmine planting pots on flattop-concrete-roof floor (36-pot Pudsaon growing) can absorb outside sensible heat to latent heat $0.12-0.15 \mathrm{cal} / \mathrm{cm}^{2} / \mathrm{min}$ which is equivalent to decreasing temperature $1.00{ }^{\circ} \mathrm{C}-1.11{ }^{\circ} \mathrm{C}$.

6) Planting green plants, especially phreatophyte, on the flattop-concrete roof is suitable for assembling in dense-populated megacity with high density of households like Bangkok city. Research result is applicable for growing trees around houses, and also for city planners on how to cool the houses and the city.

\section{Ackowledgment}

This research received financial supports from The King's Royally Initiated Laem Phak Bia Environmental Research and Development Project, Chaipattana Foundation, Thailand

\section{References}

Abou-Korin, A. A. (2014). Small-size urban settlements: Proposed approach for managing urban future in developing countries of increasing technological capacities, the case of Egypt. Ain Shams Engineering Journal, 5(2), 377-390. http://dx.doi.org/10.1016/j.asej.2013.12.001

Ahn, C., \& Mitsch, W. J. (2002). Evaluating the use of recycled coal combustion products in constructed wetland: an ecologic-economic modeling approach. Ecological Modelling, 150(1-2), 117-140. http://dx.doi.org/10.1016/S0304-3800(01)00477-X

Akbari, H., Davis, S., Dorsano, S., Huang, J., \& Winnett, S. (1992). Cooling Our Communities: A Guidebook on Tree Planting and Light-Colored Surfacing. U.S. Environmental Protection Agengy, Office of Policy Analysis, Climate Change Division, Washington, D.C. Retrieve from http://nepis.epa.gov/Exe/ZyPDF.cgi/2000G1NT.PDF?Dockey=2000G1NT.PDF

Alchapar, N. L., Correa, E. N., \& Canton, M. A. (2014). Classification of building materials used in the urban envelopes according to their capacity for mitigation of the urban heat island in semiarid zones. Energy and Buildings, 69, 22-32. http://dx.doi.org/10.1016/j.enbuild.2013.10.012

Arneth, S., \& Stichlmair, J. (2001). Characteristics of thermosiphon reboilers. International. Journal of Thermal 
Sciences, 40(4), 385-391. http://dx.doi.org/10.1016/S1290-0729(01)01231-5

Ashktorab, H., Pruitt, W. O., Paw U, K. T., \& George, W. V. (1989). Energy balance determinations close to the soil surface using a micro-Bowen ratio system. Agricultural and Forest Meteorology, 46(3), 259-274. http://dx.doi.org/10.1016/0168-1923(89)90068-3

Baver, L. D. (1966). Soil Physics (3rd ed). John Wiley \& Sons, Inc., New York, USA.

Baver, L. D., Gardner, W. H., \& Gardner, W. R. (1972). Soil Physics $\left(4^{\text {th }}\right.$ ed). John Wiley \& Sons, Inc., New York, USA.

Botkin, D. B., \& Keller, E. A. (2011). Environmental Science: Earth as a Living Planet (8th ed). John Wiley \& Sons, Inc. USA.

Bowen, I.S. (1926). The ratio of heat losses by conduction and by evaporation from any water surface. Physical Review, 27: 779-787. http://dx.doi.org/10.1103/PhysRev.27.779

Buckman, H. O., \& Brady, N. C. (1969). The Nature and Properties of Soils (7th ed), The Macmillan Company, USA.

Chun, B., \& Guldmann, J. M. (2014). Spatial statistical analysis and simulation of urban heat island in high-intensity central cities. Landscape and Urban Planning, 125, 76-88. http://dx.doi.org/10.1016/j.landurbplan.2014.01.016

Chunkao, K. (1971). An analysis of evapotranspiration of dryevergreen forest at Sakaerat, Thailand. KU Forest research Bulletin No.16. Faculty of Forestry, Kasetsart University, Bangkok, Thailand. 110 p.

Chunkao, K. (1979). Micrometeorology. Thailand: Department of Conservation, Faculty of Forestry, Kasetsart University, Bangkok, Thailand. $147 \mathrm{p}$.

Chunkao, K. (2004). Environmental Science (6 ${ }^{\text {th }}$ ed). Kasetsart University Publishing, Bangkok, Thailand. 357 p.

Coseo, P., \& Larsen, L. (2014). How factors of land use/ land cover, building configuration, and adjacent heat sources and sinks explain Urban Heat Islands in Chicago. Landscape and Urban Planning, 125, 117-129. http://dx.doi.org/10.1016/j.landurbplan.2014.02.019

Deacon, E. L. (1949). Vertical diffusion in the lowest layers of the atmosphere. Quarterly journal of the Royal Meteorological Society, 75(323), 89-103. http://dx.doi.org/10.1002/qj.49707532312

Dicken, U., Cohen, S., \& Tanny, J. (2013). Examination of the Bowen ratio energy balance technique for evapotranspiration estimates in screenhouses. Biosystems Engineering, 114(4), 397-405. http://dx.doi.org/10.1016/j.biosystemseng.2012.11.001

Ferreira, J. A., \& Condessa, B. (2012). Defining expansion areas in small urban settlements - An application to the municipality of Tomar (Portugal). Landscape and Urban Planning, 107(3), 283-292. http://dx.doi.org/10.1016/j.landurbplan.2012.06.008

Garratt, J. R. (1978). Flux profile relations above tall vegetation. Quarterly Journal of the Royal Meteorological Society, 104(439): 199-211. http://dx.doi.org/10.1002/qj.49710443915

Gates, D. M. (1965). Energy Exchange in the biosphere. New York, NY: Harber \& Brothers publisher.

Gates, D. M. (1980). Biophysical Ecology. Mineola, NY: Springer-Verlag New York, Inc.

Geiger, R., Aron, R. H., \& Todhunter, P. (2003). The Climate Near the Ground (6 $6^{\text {th }}$ ed). Rowman \& Littlefield Publishers, Inc., USA.

Hammer, D. A. (1989). Constructed Wetlands for Wastewater Treatment: municipal, industrial, and agricultural.CRC Press LLC, USA.

Hartman, D. L. (1994). Global Physical Climatology. Academic Press, California, USA.

Heilman, J. L., \& Brittin, C. L. (1989). Fetch requirements for bowen ratio measurements of latent and sensible heat fluxes. Agricultural and Forest Meteorology, 44(3-4), 261-273. http://dx.doi.org/10.1016/0168-1923(89)90021-X

Holland, S., Heitman, J. L., Howard, A., Sauer, T. J., Geise, W., Ben-Gal, A., Agam, N., Kool, D., \& Havlin, J. (2013). Micro-Bowen ratio system for measuring evapotranspiration in a vineyard interrow. Agricultural and Forest Meteorology, 177, 93-100. http://dx.doi.org/10.1016/j.agrformet.2013.04.009

Holman, J. P. (2009). Heat Transfer $\left(10^{\text {th }}\right.$ ed). McGraw-Hill, New York, USA 
Honjo, T., \& Takakura, T. (1990-1991). Simulation of thermal effects of urban green areas on their surrounding areas. Energy and Buildings, 15(3-4), 443-446. http://dx.doi.org/10.1016/0378-7788(90)90019-F

Jenssen, P. D., Maehlum, T., \& Krogstad, T. (1994). Potential use of constructed wetlands for wastewater treatment in northern environments. Water Science and Technology, 28(10), 149-157. Retrieve from http://www.iwaponline.com/wst/02810/wst028100149.htm

Juwarkar, A. S., Oke, B., Juwarkar, A., \& Patnaik, S. M. (1995). Domestic wastewater treatment through constructed wetland in India. Water Science and Technology, 32(3), 291-294. http://dx.doi.org/10.1016/0273-1223(95)00637-0

Keddy, P. A. (2010). Wetland Ecology Principles and conservation (2nd ed), Cambridge University Press, Cambridge, UK, $497 \mathrm{p}$.

Ketterer, C., \& Matzarakis, A. (2014). Human-biometeorological assessment of the urban heat island in a city with complex topography-the case of Stuttgart, Germany. Urban Climate, 10(part 3), 573-584. http://dx.doi.org/10.1016/j.uclim.2014.01.003

Kujinga, K., Vanderpost, C. Mmopelwa, G., \& Wolski, P. (2014). An analysis of factors contributing to household water security problems and threats in diferent settlement categories of Ngamiland, Botswana. Physics and Chemistry of the Earth, Parts A/B/C. 67-69: 187-201.

Lai, W., Wang, S., Peng, C., \& Chen, Z. (2011). Root features related to plant growth and nutrient removal of 35 wetland plants. Water Research, 45, 3941-3950. http://dx.doi.org/10.1016/j.watres.2011.05.002

Lee, X., Massman, W., \& Law, B. (2004). Handbook of micrometeorology: A guide for surface flux measurement and analysis. Kluwer Academic Publishers, USA.

Li, S., Zhang, K., Zhou, S., Zhang, L., \& Chen, Q. (2009). Use of dewatered municipal sludge in Canna growth in pot experiments with a barren clay soil. Waste Management, 29(6), 1870-1876. http://dx.doi.org/10.1016/j.wasman.2008.12.007

Lokoshchenko, M. A. (2014). Urban heat island in Moscow. Urban Climate, 10(part 3), 550-562. http://dx.doi.org/10.1016/j.uclim.2014.01.008

Maimaitiyiming, M., Ghulam, A. Tiyip, T., Pla, F., Latorre-Carmona, P., Halik, U., Sawut, M., \& Caetono, M. (2014). Effects of green space spatial pattern on land surface temperature: Implications for sustainable urban planning and climate change adaptation. ISPRS Journal of Photogrammetry and Remote Sensing, 89, 59-66. http://dx.doi.org/10.1016/j.isprsjprs.2013.12.010

Mangone, G., \& Van der Linden, K. (2014). Forest Microclimates: Investigating the performance potential of vegetation at the building space scale. Building and Environment, 73, 12-23. http://dx.doi.org/10.1016/j.buildenv.2013.11.012

Mcpherson, E. G., \& Rowntree, R. A. (1993). Energy conservation potential of urban tree planting. Journal of Arboriculture, 19(6), 321-331. Retrieve from http://www.sfrc.ufl.edu/urbanforestry/Resources/PDF\%20downloads/mcpherson_1993.pdf

Mcpherson, E. G., \& Simpson, J. R. (2003). Potential energy savings in buildings by an urban tree planting programme in California. Urban Forestry \& Urban Greening, 2(2), 73-86. http://dx.doi.org/10.1078/1618-8667-00025

Mcpherson, E. G. (1988). Functions of buffer plantings in urban environments. Agriculture, Ecosystems \& Environment, 22-23, 281-298. http://dx.doi.org/10.1016/0167-8809(88)90026-6

Meier, R. L., \& Quium, A. S. M. A. (1991). Planning and designing new urban settlement on estuaries: Bangladesh. Landscape and Urban Planning, 21(3), 211-226. http://dx.doi.org/10.1016/0169-2046(91)90019-I

Ng, E., Chen, L., Wang, Y., \& Yuan, C. (2012). A study on the cooling effects of greening in a high-density city: An experience from Hong Kong. Building and Environment, 47, 256-271. http://dx.doi.org/10.1016/j.buildenv.2011.07.014

Odum, E.P. \& Barrett, G.W. (2004). Fundamentals of Ecology (5th ed). Thomson Brooks/Cole, UK, 598 p.

Oke, T. R., Johnson, G. T., Steyn, D. G., \& Watson, I. D. (1991). Simulation of surface urban heat islands under ideal conditions at night - Part 2: Diagnosis and causation. Boundary-Layer Meteorology, 56, 339-358. http://dx.doi.org/10.1007\%2FBF00119211 
Perez, P. J., Castellvi, F., Ibanez, M., \& Rosell, J. I. (1999). Assessment of reliability of Bowen ratio method for partitioning fluxes. Agricultural and Forest Meteorology, 97(3), 141-150. http://dx.doi.org/10.1016/S0168-1923(99)00080-5

Santamouris, M. (2001). Energy and climate in the Urban Built Environment. James \& James (Science Publishers) Ltd, London, UK.

Santamouris, M. (2014). Cooling the cities - A review of reflective and green roof mitigation technologies to fight heat island and improve comfort in urban environments. Solar Energy, 103, 682-703. http://dx.doi.org/10.1016/j.solener.2012.07.003

Savage, M. J., Everson, C. S., \& Metelerkamp, B. R. (2009). Bowen ratio evaporation measurement in a remote montane grassland: Data integrity and fluxes. Journal of Hydrology, 376(1-2), 249-260. http://dx.doi.org/10.1016/j.jhydrol.2009.07.038

Sellers, W. D. (1965). Physical Climatology. Chicago: The University of Chicago Press, 272 p.

Shahidan, M. F., Jones, P. J., Gwillium, J., \& Salleh, E. (2012). An evaluation of outdoor and building environment cooling achieved through combination modification of trees with ground materials. Building and Environment, 58, 245-257. http://dx.doi.org/10.1016/j.buildenv.2012.07.012

Skoulika, F., Santamouris, M., Kolokotsa, D., \& Boemi, N. (2014). On the thermal characteristics and mitigation potential of a medium size urban park in Athens, Greece. Landscape and Urban Planning, 123, 73-86. http://dx.doi.org/10.1016/j.landurbplan.2013.1r1.002

Sun, Y., \& Augenbroe, G. (2014). Urban heat island effect on energy application studies of office buildings. Energy and Buildings, 77, 171-179. http://dx.doi.org/10.1016/j.enbuild.2014.03.055

Takebayashi, H., Kimuara, Y., \& Kyogoku, S. (2014). Study on the appropriate selection of urban heat island measure technologies to urban block properties. Sustainable Cities and Society, 13, 217-222. http://dx.doi.org/10.1016/j.scs.2014.01.008

Verma, S. B., Rosenberg, N. J., \& Blad, B. L. (1978). Turbulent exchange coefficients for sensible heat and water vapor under advection conditions. Journal of Applied Meteorology, 17, 330-338. Retrieve from: ftp://195.37.229.5/pub/outgoing/jwinder/BowenRatioLiterature/Verma_JApplMeteo_1977.pdf

Vollmer, D., \& Gret-Regamey, A. (2013). Rivers as municipal infrastructure: Demand for environmental services in informal settlements along an Indonesian river. Global Environmental Change, 23(6), 1542-1555. http://dx.doi.org/10.1016/j.gloenvcha.2013.10.001

Ward, P. M., \& Peters, P. A. (2007). Self-help housing and informal homesteading in peri-urban America: Settlement identification using digital imagery and GIS. Habitat International, 31(2), 205-218. http://dx.doi.org/10.1016/j.habitatint.2007.02.001

Wolf, A., Saliendra, N., Akshalov, K., Johnson, D. A., \& Laca, E. (2008). Effects of different eddy covariance correction schemes on energy balance closure and comparisons with the modified Bowen ratio system. Agricultural and Forest Meteorology, 148(6-7), 942-952.

Zhang, Z., Lv, Y., \& Pan, H. (2013). Cooling and humidifying effect of plant communities in subtropical urban parks. Urban Forestry \& Urban Greening, 12(3), 323-329. http://dx.doi.org/10.1016/j.ufug.2013.03.010

\section{Copyrights}

Copyright for this article is retained by the author(s), with first publication rights granted to the journal.

This is an open-access article distributed under the terms and conditions of the Creative Commons Attribution license (http://creativecommons.org/licenses/by/3.0/). 